IZA DP No. 10295

Trade Liberalization and Child Labor in China

Liqiu Zhao

Fei Wang

Zhong Zhao

October 2016 


\title{
Trade Liberalization and Child Labor in China
}

\author{
Liqiu Zhao \\ Renmin University of China \\ Fei Wang \\ Renmin University of China \\ Zhong Zhao \\ Renmin University of China \\ and IZA
}

\section{Discussion Paper No. 10295 \\ October 2016}

\author{
IZA \\ P.O. Box 7240 \\ 53072 Bonn \\ Germany \\ Phone: +49-228-3894-0 \\ Fax: +49-228-3894-180 \\ E-mail: iza@iza.org
}

\begin{abstract}
Any opinions expressed here are those of the author(s) and not those of IZA. Research published in this series may include views on policy, but the institute itself takes no institutional policy positions. The IZA research network is committed to the IZA Guiding Principles of Research Integrity.

The Institute for the Study of Labor (IZA) in Bonn is a local and virtual international research center and a place of communication between science, politics and business. IZA is an independent nonprofit organization supported by Deutsche Post Foundation. The center is associated with the University of Bonn and offers a stimulating research environment through its international network, workshops and conferences, data service, project support, research visits and doctoral program. IZA engages in (i) original and internationally competitive research in all fields of labor economics, (ii) development of policy concepts, and (iii) dissemination of research results and concepts to the interested public.
\end{abstract}

IZA Discussion Papers often represent preliminary work and are circulated to encourage discussion. Citation of such a paper should account for its provisional character. A revised version may be available directly from the author. 


\section{ABSTRACT}

\section{Trade Liberalization and Child Labor in China*}

This paper exploits a quasi-natural experiment - the U.S. granting of Permanent Normal Trade Relations (PNTR) to China after China's accession to the World Trade Organization to examine whether trade liberalization affects the incidence of child labor in China. PNTR permanently set U.S. duties on Chinese imports at low Normal Trade Relations (NTR) levels and removed the uncertainty associated with annual renewals of China's NTR status. We find that the PNTR was significantly associated with the rising incidence of child labor in China. A one percentage point decrease in average export tariffs raises the odds of child labor by a 1.3 percentage point. The effects are greater for girls, older children, rural children, and children with less-educated parents. The effect of trade liberalization on the incidence of child labor, however, disappears in the long run, because trade liberalization can induce exporters to upgrade technology and thus have less demand for unskilled workers.

JEL Classification: F14, F16

Keywords: child labor, trade liberalization, trade policy uncertainty, difference-in-differences, China

Corresponding author:

Zhong Zhao

School of Labor and Human Resources

Renmin University of China

59 Zhongguancun St.

Beijing 100872

China

E-mail: mr.zhong.zhao@gmail.com

\footnotetext{
${ }^{*}$ We are thankful for the helpful comments from seminar participants at the Institute for Economic and Social Research at Jinan University, the Research Institute of Economics and Management at Southwestern University of Finance and Economics, the Guanghua School of Management at Peking University, and conference participants at the Transition from School to Work Seminar at Renmin University of China, the 2016 Annual Conference of the Population Association of America at Washington, D.C., the 2016 China Labor Economist Forum at Hunan University, and the 2016 Shanghai Forum of the Young Economist Society. Liqiu Zhao acknowledges financial support from the Natural Science Foundation of China (Grant No. 71403286) and the Center for Labor Economics and Public Policy at Zhejiang University. Zhong Zhao acknowledges financial support from the Special Fund for Building World-Class Universities and Disciplines through the Renmin University of China (Grant No. 16XNL005). This research uses data from China Health and Nutrition Survey (CHNS). We thank the National Institute for Nutrition and Health, China Center for Disease Control and Prevention, Carolina Population Center (P2C HD050924, T32 HD007168), the University of North Carolina at Chapel Hill, the NIH (R01-HD30880, DK056350, R24 HD050924, and R01-HD38700) and the NIH Fogarty International Center (D43 TW009077, D43 TW007709) for financial support for the CHNS data collection and analysis files from 1989 to 2015 and future surveys, and the China-Japan Friendship Hospital, Ministry of Health for support for CHNS 2009, Chinese National Human Genome Center at Shanghai since 2009, and Beijing Municipal Center for Disease Prevention and Control since 2011. All views and the remaining errors are the authors' alone.
} 


\section{Introduction}

Trade liberalization has yielded prominent economic benefits to developing countries (Edwards, 1993; Greenaway et al., 2002), yet its effect on human capital, an engine for long-term economic development, remains controversial (Edmonds, 2008). On the one hand, trade liberalization may create employment opportunities for cheap and unskilled child labor (Maskus, 1997), and children's labor force participation may have adverse effects on their education (Heady, 2003; Ray, 2003; Gunnarsson et al., 2006) and health (Parker, 1997; Kassouf et al., 2001; O’Donnell et al., 2005) and may suppress their human capital accumulation and future wages. On the other hand, trade liberalization could raise household income and decrease the incidence of child labor (Edmonds and Pavcnik, 2006; Davies and Voy, 2009). This paper investigates the effect of a trade liberalization shock, i.e., the U.S. granting of Permanent Normal Trade Relations (PNTR) to China after China's accession to the World Trade Organization (WTO) on December 11, 2001, on the incidence of child labor in China. ${ }^{1}$ This paper aims to provide more evidence on the relationship between globalization and human capital accumulation from the perspective of child schooling and working decisions in developing countries.

The relationship between trade and child labor has received considerable attention. Cigno et al. (2002), Neumayer and De Soysa (2005), Edmonds and Pavcnik (2006) and Davies and Voy (2009), among others, examine whether there is any link between trade and child labor using cross-country comparison. However, the potential endogeneity of trade has been largely ignored by the cross-country studies. For example, omitted labor standards are correlated with both trade flows and the likelihood of child labor (Maskus, 1997; Busse, 2002). Edmonds and Pavcnik (2006) and Davies and Voy (2009) attempt to address the endogeneity of openness by instrumenting for openness with trade based on a country's geography, i.e., the distance between two countries and whether the two countries share a common

\footnotetext{
${ }^{1}$ Permanent Normal Trade Relations is a U.S. term for the familiar principle of Most Favored Nation, which was changed to PNTR in 1998 in the U.S.
} 
language, border, or landlocked status. However, these two studies rely on cross-sectional data analyses. Cross-sectional data analysis is difficult to control for regional heterogeneity stemming from geography, which may affect child labor, for example, the quality of institutions, as discussed in Edmonds and Pavcnik (2006). ${ }^{2}$ A number of studies have examined the relationship between trade liberalization and child labor based on micro data. For example, Edmonds and Pavcnik (2005) employ household level data in Vietnam during its episode of rice market liberalizations and find that the liberalization was associated with declines in child labor. Edmonds et al. (2010) and Kis-Katos and Sparrow (2011) identify the child labor effect of trade through geographic and temporal variation in exposure to tariff reductions. However, tariff reductions are likely to be endogenous (Mayer, 1984; Gawande et al., 2006). For example, tariff changes might be influenced by lobbying groups.

One major contribution of this paper is that it identifies the causal effect of trade liberalization on the incidence of child labor by exploiting a quasi-natural experiment arising from the change in U.S. trade policy upon China's accession to the WTO in 2001. Although China's exports to the U.S. had been subject to the relatively low normal trade relations (NTR) tariff rates reserved for WTO members since 1980, these low rates required annual renewals that were uncertain and politically contentious. Without renewal, U.S. import tariffs on Chinese goods would have jumped to higher non-NTR tariff rates assigned to nonmarket economies, which were originally established under the Smoot-Hawley Tariff Act of 1930. Thus, the PNTR, which was passed by the U.S. Congress in October 2000 and became effective upon China's accession to the WTO, removed the uncertainty associated with these annual renewals and permanently set the U.S. duties on Chinese imports at NTR levels. The reduction in trade policy uncertainty is associated with increased entry into exporting (Handley, 2014; Handley and Limao, 2013, 2015). The U.S. was China's largest trade partner in $2000 .{ }^{3}$ The changes in U.S. trade policy are expected to substantially

\footnotetext{
${ }^{2}$ A country's geography plays an important role in shaping its economic and political institutions (Acemoglu et al., 2005).

${ }^{3}$ In 2000, the total value of U.S. trade in goods (export and import) with China amounted to 74.46 billion U.S. dollars, which accounted for $15.7 \%$ of China's total exports and imports.
} 
influence the trade volume of China. Pierce and Schott (2016) show that the PNTR is associated with statistically significant increases in the export value of China. Specifically, industries with higher NTR gaps, that is, the difference between the non-NTR and the NTR tariff rates, experience larger trade policy shocks. Moreover, regions with higher employment shares in industries with higher NTR gaps experience a larger boost in export value. Thus, we can identify the impact of trade liberalization on child labor using two sources of sample variation: the variation between regions with high and low NTR gaps and the variation before and after the PNTR. Specifically, we use a difference-in-differences (DID) strategy to identify the causal effect of trade liberalization on child labor. Our generalized DID identification strategy tests whether the difference in the incidence of child labor between regions with higher NTR gaps and those with lower NTR gaps is greater after the change in policy than the difference in the incidence of child labor between the two types of regions in the pre-PNTR era. This strategy allows for the control of time-invariant differences across regions (for example, unobserved regional institutions such as labor standards related to child labor). Furthermore, the NTR gaps used in our specification had been set long before China's accession to the WTO and are thus likely to be exogenous.

Another contribution of this paper is that it is among the few studies that explore the issue of child labor in China. According to Maplecroft's 2014 Child Labor Index, ${ }^{4}$ China was classified as being at "extreme risk" of using child labor. Nevertheless, very few studies have investigated the issue of child labor in China, which is the largest developing country. ${ }^{5}$ Our paper is the first study relating trade liberalization to child labor in the context of China, which experienced dramatic trade liberalization in

\footnotetext{
${ }^{4}$ Maplecroft's 2014 Child Labor Index evaluates the frequency and severity of reported child labor incidents in 197 countries. China ranks 20th in child labor risks among 197 countries.

5 De Brauw and Giles (2016) is one of the few studies that examines how the schooling activities of rural children are influenced by urban labor markets to which they could migrate and finds that schooling enrollment declines with the opportunity to migrate. Two recent studies have investigated the issue of child labor in China. He (2016) estimates the relationship between child labor and a child's academic achievement and concludes that child labor is not a substantial problem in China. However, her analysis is based on children aged between 9 and 13 years who are still enrolled in school. In contrast, Tang et al. (2016) show that child labor is not a negligible social phenomenon in China and approximately $7.74 \%$ (weighted by sampling weight) or $9.41 \%$ (unweighted) of children aged between 10 and 15 years were engaged in labor in 2010 .
} 
the early 2000 s.

In this paper, we show that a one percentage point permanent decrease in tariff rates is associated with a 1.3 percentage point increase in the incidence of child labor, which implies that child labor meets the rising demand for unskilled workers created by trade liberalization. The effects are greater for girls, older children, rural children, and children with less-educated parents. Trade liberalization in China also creates more employment opportunities for less-educated mothers and makes their children more likely to do housework, which might crowd out children's time for study. Therefore, trade liberalization in China may have enlarged the education gaps between boys and girls, urban and rural children, and between children with more-educated parents and those with less-educated parents. The effect of trade liberalization on the incidence of child labor, however, disappears in the long run, one reason being that trade liberalization has induced exporters to upgrade technology and thus decrease their demand for unskilled workers.

The rest of the paper is organized as follows. Section 2 describes the dataset used in the paper. Section 3 introduces the measure of China's trade liberalization. Section 4 describes our empirical specifications and main results and discusses additional results. Section 5 concludes.

\section{Data}

\subsection{China Health and Nutrition Survey}

The data used in this study are from the China Health and Nutrition Survey (CHNS), which is conducted by the Carolina Population Center at the University of North Carolina at Chapel Hill and the National Institute of Nutrition and Food Safety at the Chinese Center for Disease Control and Prevention. The CHNS is a longitudinal dataset with nine survey waves (1989, 1991, 1993, 1997, 2000, 2004, 2006, 2009, 2011). We drop the 1989 wave of the CHNS, due to the data concerns described in the 
previous studies. ${ }^{6}$ Moreover, because the wave of 1989 is far from 2001, when the U.S. granted the PNTR to China, the exclusion of the 1989 wave does not change our results. The survey covers 9 provinces: Guangxi, Guizhou, Heilongjiang, Henan, Hubei, Hunan, Jiangsu, Liaoning and Shandong. The survey thus covers coastal as well as inland provinces and accounts for $43.11 \%$ of the total population in China in 2000.

The household survey contains detailed demographic, economic, time use, labor force participation, asset ownership, and expenditure information. The community survey collects information on community infrastructure, services, population, prevailing wages, and related variables. Importantly, children under age 18 in the survey are required to report their work status. This dataset provides us a unique opportunity to examine the relationship between trade liberalization and child labor in China.

\subsection{Definition of Child Labor}

There is no consensus regarding the definition of child labor in the literature (Tang et al., 2016). The definition officially employed by the International Labor Organization (ILO) depends on whether the work is harmful to a child's development.

Child labor refers to the employment of children in any work that deprives children of their childhood, interferes with their ability to attend regular school, and that is mentally, physically, socially or morally dangerous and harmful.

$$
\text { "What is child labor?" ILO. } 2012 .
$$

The Convention concerning Minimum Age for Admission to Employment (International Labour Organization, 1973) stipulates that countries are free to specify a minimum age for labor, with a minimum of 15 years. Moreover, any work that is likely to jeopardize children's physical, mental or moral health, safety or morals should not be done by anyone under the age of 18. In China, three relevant laws,

\footnotetext{
${ }^{6}$ There are some concerns about the quality of the income information in the first wave of the CHNS. Additionally, the workforce participation of children was abnormally high in 1989, i.e., more than $90 \%$.
} 
namely, the Labor Law of the People's Republic of China (Article 15), Regulations Banning Child Labor (Article 2) and the Law of the People's Republic of China on the Protection of Minors (Article 28), stipulate that state organs, social bodies, enterprises, institutions, non-governmental not-for-profit organizations and private businesses are prohibited from employing children under the age of 16. Additionally, adolescent workers (aged 16 to 18 ) are protected from any over-strenuous, poisonous or harmful labor or any dangerous operation by the Law of the People's Republic of China on the Protection of Minors (Article 28).

In this paper, we define child labor as children aged between 6 and 17 years who are economically active in the labor markets, i.e., either working or seeking employment. ${ }^{7}$ China's laws justify our definition of child labor in the sense that the labor force participation of children aged 6-17 has been associated with negative impacts on education and health, as described in the definition of child labor by the ILO. In the CHNS, only children who are not in school are required to report their work status, so our analysis is restricted to children who do not enroll in school. In 2010, 8.9\% (unweighted by sampling weight) of children aged from 10 to 15 years old combine economic activity with schooling (Tang et al., 2016), we may underestimate the trade effect on the incidence of child labor. Thus, this study can be seen as a lower bound of the effect.

Table 1 shows the incidence of child labor in China over the period 1991-2011. Overall, $10.6 \%$ of children are engaged in child labor, and the incidence of child labor declines over time. The overall likelihood of child labor for boys is similar to that for girls. The likelihood of child labor increases with the age of children, reaching a critically high level for children aged 16-17. A possible reason is that the 9-year compulsory education system in China requires that all children attend school for a minimum of 9 years, and a child is likely to complete his/her required education at age 15. Moreover, child labor is more prevalent in rural than in urban areas. Children with less-educated parents or low household per capita income are more likely to be

\footnotetext{
${ }^{7}$ We also use the information on the specific reasons for not living at home to trace children employed away from home. Specifically, a child is defined as working if the response is "seeking employment elsewhere".
} 
child laborers.

[Table 1 about here]

\section{Measuring the Effect of PNTR}

\subsection{Background of PNTR}

Before 1980, as a nonmarket-economy country, China's exports to the U.S. were subject to relatively high tariff rates originally set under the Smoot-Hawley Tariff Act of 1930. The Smoot-Hawley Tariffs, known as "non-NTR" or "column 2" tariffs, are often substantially higher than the "NTR" or "column 1" rates the U.S. offers fellow members of the WTO. In 1980, shortly after the establishment of diplomatic relations between the United States and the People's Republic of China, the U.S. started to grant China NTR status on an annual basis under Jackson-Vanik waiver provisions of the U.S. Trade Act of 1974. Since 1980, China's normal trade status has had to be renewed annually.

Prior to 1989, China had received the waiver routinely from executive orders of U.S. Presidents. After the 1989 Tiananmen Square incident, although the presidential waiver continued, the U.S. Congress began to exert strong pressure opposing normal trade status renewal. From 1990 to 2001, the average House vote against annual NTR renewal was 38 percent. Table A1 summarizes the House votes by year. ${ }^{8}$ The uncertainty of the renewal of China's NTR status discouraged U.S. firms from trading with and investing in China.

The U.S. House of Representatives passed legislation to grant the PNTR to China on May 24, 2000, which went into effect on January 1, 2002, after China joined the WTO. The U.S. granting of PNTR to China ended the uncertainty associated with

\footnotetext{
${ }^{8}$ If the U.S. House and Senate are both against the proposal of granting the NTR to China, the U.S. president could choose to veto Congress' decisions. Consequently, the House and Senate both needed two-thirds votes to override the president's veto. China was eventually able to receive the NTR status every year after 1989, but the U.S. Congress nearly succeeded in overriding the president's veto in 1991 and 1992.
} 
annual renewals of China's NTR status, thereby leading to greater China-U.S. trade. ${ }^{9}$

\subsection{The NTR Gap}

Following Pierce and Schott (2016), we quantify the impact of U.S. trade policy on industry $i$ as the difference between the non-NTR rate to which tariffs would have risen had annual renewal failed and the NTR tariff rate that was ensured by PNTR,

$$
\text { NTR Gap } \text { Gon NTR Rate }_{i}-\text { NTR Rate }_{i}
$$

We compute NTR gaps using ad valorem equivalent NTR and non-NTR tariff rates for 2000 provided by Feenstra et al. (2002), set at the 8-digit Harmonized System (HS) level. ${ }^{10}$ We compute export-weighted 3-digit industry-level NTR gaps using concordances provided by Dean and Lovely (2010). ${ }^{11}$ Industries with larger NTR gaps in China are expected to be affected more by the change in U.S. trade policy. ${ }^{12}$ The most attractive feature of this measure of trade shock is its exogeneity. Seventy-nine percent of the variation in the NTR gap across industries arises from variation in non-NTR rates, which was set 70 years prior to the passage of PNTR. Moreover, the NTR gap exhibits substantial variation across industries: in 2000, the average NTR gap is 33 percentage points, with a standard deviation of 15 percentage points. Figure A1 illustrates the distribution of NTR gaps across manufacturing industries. $^{13}$

Regions in China differ markedly in industrial composition prior to the accession to the WTO and thus have differential NTR gaps. By applying the provincial pre-entry industrial composition of employment computed based on the $0.1 \%$ sample of the 2000 Population Census data in China, the province-level NTR gap is defined as

\footnotetext{
${ }^{9}$ The negative effect of uncertainty on investment is consistent with a range of theoretical and empirical applications. Schwartz and Zozaya-Gorostiza (2003) find that input cost uncertainty lowers incentives to invest in new information technology. Handley (2014) and Handley and Limao (2013, 2015) show that the reduction in destination-country trade policy uncertainty is associated with increased entry into exporting.

${ }^{10}$ Note that our results are robust to using the NTR gaps from any available year.

${ }^{11}$ More specifically, we use the concordance between CIC (China Industrial Classification) 2002 and ISIC Rev3 (International Standard Industrial Classification of All Economic Activities, Rev.3) and the concordance between ISIC rev3 and HS1996.

${ }_{12}$ Pierce and Schott (2016) show that industries with higher NTR gaps experience disproportionate increases in the number of Chinese firms exporting to the U.S.

${ }^{13}$ The NTR gaps range from 0 (e.g., oil and crude petroleum) to 70 (e.g., dolls, stuffed toys, children's vehicles, and alcohol manufacturing) percentage points.
} 


$$
\text { NTR Gap } r=\frac{\sum_{j} \text { Worker }_{r, j, 2000}}{\text { Total workers }_{r, 2000}} \times N T R \operatorname{Gap}_{j}
$$

where Worker $_{r, j, 2000}$ is the employment in industry $j$ in province $r$ in the year 2000 and Total workers $_{r, 2000}$ is the total employment in province $r$ in the year 2000. NTR Gap is the NTR gap for industry $j$ in the year 2000. Thus, the province-level NTR gap is the employment-weighted average of NTR gaps for 3-digit industries. Because the tariff rates from Feenstra et al. (2002) are only available for the manufacturing sector, we can construct the provincial NTR gaps based on manufacturing sectors. Doing so does not invalidate our analysis, as $89.78 \%$ of exports from China were manufactured goods in 2000. Moreover, trade in services is more prevalent in "high-tech" industries, for instance, telecommunications, transport and distribution services, and financial intermediation (Francois and Hoekman, 2010), which is unlikely to affect low-skilled child labor. Table 2 reports employment-weighted average NTR gaps across surveyed provinces in the CHNS dataset, ranging from 1.13 in Guizhou province to 6.71 in Jiangsu province.

[Table 2 about here]

Provinces with higher NTR gaps experience dramatic increases in the value of exports and imports after China's entry into the WTO. Figure 1 shows the average export and import in provinces with higher NTR gaps and provinces with lower NTR gaps over the period 1991-2011. ${ }^{14}$ China's WTO accession in 2001 shifted the value of exports and imports in provinces with higher NTR gaps to a greater level relative to that in provinces with lower NTR gaps.

[Figure 1 about here]

Figure 2 illustrates the incidence of child labor in provinces with higher NTR gaps and provinces with lower NTR gaps over the period 1991-2011. Before China's entry into the WTO, the likelihood of child labor follows the same time trend and is higher in provinces with lower NTR gaps, which are mostly inland and relatively poor. However, after 2001, the incidence of child labor in provinces with higher NTR gaps

\footnotetext{
${ }^{14}$ Based on the NTR gaps in Table 2, the four provinces with higher NTR gaps are Jiangsu, Liaoning, Shandong, and Hubei. The five provinces with lower NTR gaps are Heilongjiang, Hunan, Henan, Guangxi, and Guizhou.
} 
increases sharply and is higher than that in provinces with lower NTR gaps. Figure 2 provides indicative evidence of a positive relationship between the PNTR and the incidence of child labor.

[Figure 2 about here]

\section{PNTR and Child Labor}

\subsection{Overall effects of PNTR on child labor}

\subsubsection{Baseline specification}

We analyze the effect of trade liberalization shock arising from the changes in the U.S. trade policy on child labor using a generalized difference-in-differences (DID) specification. More specifically, the effect of trade liberalization on child labor can be identified by examining whether the incidence of child labor in regions with higher NTR gaps (first difference) is higher/lower after the imposition of PNTR (second difference). The sample includes children aged 6-17 from CHNS over the period 1991 to 2011 .

The baseline empirical specification is,

$$
\text { ChildLabor }_{\text {irt }}=\beta_{0}+\beta_{1} \cdot \text { Post }_{t} \times N T R \text { Gap }_{r}+\theta X_{i t}+\delta H_{i t}+\lambda_{r}+\lambda_{t}+\varepsilon_{\text {irt }}
$$

where the dependent variable ChildLabor $_{\text {irt }}$ is an indicator of whether a child $i$ in province $r$ engages in child labor in year $t$. Post $t$ is a period dummy indicating the year after 2001. The interaction of the NTR gap and the indicator for the post-PNTR period is the DID term of interest. The coefficient $\beta_{1}$ captures the impact of trade liberalization on child labor in high-NTR gap regions relative to low-NTR gap regions. In the regression, we also control for a vector of observable individual characteristics $X_{i t}$, including age, age squared, gender, birth cohort dummies, and an urban dummy of a child, and a set of household characteristics $H_{i t}$, including household size group dummies, mother's and father's age and age squared, mother's and father's educational levels, and household income per capita (excluding the income from child 
labor whenever applicable). We further include province fixed effects $\lambda_{r}$ to control for time-invariant provincial characteristics, such as labor standards and quality of institutions, and year fixed effects $\lambda_{t}$ to capture the impact of common macroeconomic shocks to all regions.

Table 3 reports the baseline results of the DID estimation. Robust standard errors are clustered at the province level. To avoid the asymptotic inconsistency generated by using a small number of clusters, all our regression models use the wild bootstrapping method proposed by Cameron et al. (2008). ${ }^{15}$ All columns of regressions include province fixed effects and year fixed effects. The first column includes only the DID term; the second column adds individual characteristics; and the third column further controls for household characteristics. Unobserved province-specific characteristics, which are associated with child labor, may vary over time. Therefore, the last column additionally includes province-specific linear year trends.

[Table 3 about here]

As indicated in column (1) of Table 3, without controlling for additional covariates, the estimate for the DID term is positive but not statistically significant. When additional covariates are added in columns (2)-(4), the estimates for the DID term become statistically significant. The estimate in column (4), which controls for all covariates, indicates that the estimated effect is also economically significant, and a one percentage point decrease in China's export tariffs to the U.S after joining the WTO is associated with a 1.3 percentage point increase in the incidence of China's child labor. As shown in Table 2, the highest NTR gap is 6.71 in Jiangsu province, which is 5.58 percentage points higher than that in Guizhou province, which has the lowest NTR gap. Our estimate implies that the accession to the WTO increases the incidence of child labor in Jiangsu province by 7.25 percentage points relative to that

\footnotetext{
15 The estimation of cluster-robust standard errors is only valid for a very large number of clusters. Regression models with a small number of clusters tend to over-reject the null hypothesis of the insignificance of regression coefficients. We perform wild bootstrapping in Stata using cgmwildboot.ado. It was run with 1,500 repetitions and a null hypothesis of zero imposed for all variables.
} 
in Guizhou province.

Children's gender does not have a significant effect on the likelihood of child labor. Older children and children from larger families are more likely to participate in labor markets, while urban children and children with better-educated parents or from households with higher per capita income are less likely to engage in child labor.

Trade liberalization, on the one hand, may increase firms' demand for child labor, but on the other hand, it may decrease the incidence of child labor by raising household income. Columns (1) and (2) imply that the expanding demand for child labor dominates the negative effects of household income on child labor, and the overall effects of the PNTR on child labor tend to be positive. After controlling for household income per capita in columns (3) and (4), the child labor effects of trade liberalization become greater.

Trade liberalization increases the incidence of child labor because low-skilled intensive industries tend to experience larger trade policy shocks and thus expand more rapidly, which boosts demand for unskilled child labor. Figure 3 confirms the argument. In Figure 3, we apply the percentage of workers with junior high education or below in an industry in 2000 as a proxy for the low-skilled intensity of the industry. Figure 3 shows that lower-skilled industries have higher NTR gaps, suggesting that industries with a larger share of low-skilled workers expand more rapidly in trade liberalization.

[Figure 3 about here]

\subsubsection{Placebo test and dynamic effects}

The key assumption for the DID strategy is that the incidence of child labor in all regions follows the same time trend in the absence of the trade liberalization shock. In other words, the difference in the incidence of child labor between provinces with higher and lower NTR gaps should remain stable over time before the PNTR. To test this hypothesis, we replace the Post $_{t} \times N T R$ Gap $_{r}$ indicator used in equation (3) with interactions of the NTR Gap and the full set of year dummies, 


$$
\begin{gathered}
\text { ChildLabor }_{\text {irt }}=\beta_{0}+\sum_{y=1991}^{2011}\left(\beta_{y} 1\{y=t\} \times N T R \text { Gap }_{r}\right)+\theta X_{i t}+\delta H_{i t}+\lambda_{r}+ \\
\lambda_{t}+\varepsilon_{\text {irt }}
\end{gathered}
$$

In addition to testing for parallel pre-treatment trends for the DID estimation, equation (4) can investigate the dynamic effects of the PNTR on child labor.

Table 4 extends our regressions by including interactions of the NTR gap with each year indicator, the interaction with the year 2000 being the base group. The dependent variable in columns (1)-(4) is a dummy indicating whether a child is engaged in child labor. All columns of regressions include province fixed effects and year fixed effects. In column (1), we only control for the interactions of the NTR gap and the full set of year dummies. As indicated in column (1) of Table 4, estimates are statistically insignificant at the 5\% level before the year 2001, justifying the parallel trends identification assumption, which is crucial to our DID analysis. The interaction terms become statistically significant after the year 2001, specifically for 2004 and 2006. More interestingly, the interactions for years after 2001 imply decreasing effects of trade liberalization over time.

[Table 4 about here]

In column (2), we add the characteristics of children, and we further control for the characteristics of households in column (3). The results suggest that the basic results are robust to the inclusion of individual and household characteristics. In column (4), we further include province-specific linear year trends. After controlling for province-specific time trends, the parallel trends assumption still holds, and the effects of trade liberalization on the incidence of child labor remain robust and show similar temporal patterns as column (1).

One possible reason for the diminishing effects of PNTR on child labor is that the accession to the WTO sharply increased the demand for export goods, and incumbent firms that were not fully adapted had to temporarily hire underage workers to accomplish rapidly increased orders. As time went by, firms in China may have undertaken trade-induced skill-biased technological change, which took the form of 
increased imports of cheap machines, office equipment, and other capital goods that are complementary to skilled labor. Thus, the total number of low-skilled laborers needed by exporting industries gradually fell, and child laborers were among the first to exit the labor markets. Figure 4 confirms that industries with higher NTR gaps experience more-rapid skill upgrading. We proxy the skill upgrading of an industry by the change in percentage of employment with senior high or above education of the industry from 2004 to 2008, which is calculated based on the data from the first and second national economic censuses. Figure 4 implies that industries that are more involved in trading have shrunk their demand for low-skilled labor more rapidly over time than those with lower NTR gaps.

[Figure 4 about here]

Another possible reason is that the collapse of international trade during the 2008-2009 financial crisis may have reduced the demand for unskilled workers, and thus, the incidence of child labor declined. Figure 1 illustrates a rapid recovery in trade for China in 2011. However, as shown in Table 4, the interaction term for the year 2011 is insignificant, implying that the decreasing effect of trade liberalization over time is unlikely to be driven by the financial crisis.

\subsubsection{Confounding factors}

The DID strategy assumes that no other shocks, which may affect the incidence of child labor differently in different provinces, occurred around the same time as trade liberalization. However, China has carried out large-scale closures and mergers of rural schools since 2001. As a result, a large number of rural schools have been merged or closed. Students in remote villages were transferred to larger county or township schools, increasing the cost of education. These large-scale closures and mergers of rural schools may increase the dropout rate and, thus, the incidence of child labor. If more closures and mergers of rural schools take place in less-developed inland provinces, our estimates of the trade effect will tend to be biased.

To address this issue, in Table 5, we control for the accessibility of schools in the 
regression. More specifically, we include indicators of whether a community or a village has a primary school, junior high school or senior high school in year $t$ in column (1). In column (2), we control for the distances to the nearest primary school, junior high school and senior high school. The distance to a school measures how many kilometers the nearest school is from a community or a village. If a community or a village has a school, its distance to the school is 0 . We add a constant 0.1 to all distances before taking the logarithm of the distance. Because school mergers or closures mainly occurred in rural areas, columns (3) and (4) restrict the analysis to the rural sample and use the same specifications as in columns (1) and (2). Table 5 indicates that after controlling for the accessibility of schools, the DID term remains positive and statistically significant, except that in column (1), with a magnitude somewhat smaller in absolute value than that in Table 4.

[Table 5 about here]

Additionally, China launched the New Cooperative Medical Scheme (NCMS) pilots in July 2003, which aimed to provide health coverage for the nation's entire rural population by 2010 . The access to public health insurance may decrease the use of child labor when households experience negative health shocks (Liu, 2016). Because the NCMS pilots were first introduced in economically more-developed counties, our estimates of trade effects might be downward biased without controlling for the NCMS.

In Table 6, we control for a dummy (NCMS) indicating whether a community or a village has implemented the NCMS. In the community survey, government officials from each community were required to report whether the Cooperative Medical Scheme (CMS) had been implemented in their community and, if so, the starting date. Because the pilot implementation of the NCMS started in July 2003, only a CMS that started after 2003 is defined as an NCMS. Thus, NCMS is set to be zero for all communities/villages before 2004 and is assumed to be equal to CMS in 2004 and thereafter. As shown in Table 6, the NCMS decreases the incidence of child labor, though the effect is not statistically significant. The DID term remains negative and 
statistically significant, with a magnitude somewhat larger in absolute value than that in Table 4.

[Table 6 about here]

The results in Table 5 and 6 suggest that our findings are robust to the control for these two policy shocks concurred with the U.S. granting of PNTR to China.

\subsubsection{Source and working status of child labor}

Trade liberalization may create employment opportunities for children who have already been out of school. Thus, the increased employment opportunities may raise household income for the poor rather than reduce human capital accumulation. In column (1) of Table 7, we examine the impact of PNTR on the dropout rate using the same DID specification applied for the incidence of child labor. The results show that a one percentage point increase in the NTR gap leads to a 1.6 percentage point increase in the dropout rate. The magnitude of the trade effect on the dropout rate is similar to the effect on the incidence of child labor, implying that trade liberalization induces more children to participate in labor market at the cost of dropping out of school.

[Table 7 about here]

In the previous sections, we define children who are economically active as child labor. To examine whether trade liberalization creates more employment opportunities for low-skilled child labor or just induces more children to search for jobs, we construct dummies indicating whether a child is working or whether a child is seeking a job as dependent variables in columns (2) and (3), respectively. Trade liberalization has a significantly positive effect on the probability of working, but it does not have a significant impact on the likelihood of seeking jobs. In other words, trade liberalization decreases the unemployment rate of child labor.

\subsection{Heterogeneous Effects of PNTR on Child Labor}

In this section, we investigate whether the impact of the trade liberalization shock 
on child labor depends on the characteristics of children and households. The first part shows the direct heterogeneous effects of PNTR on child labor, and the second part studies how the PNTR would indirectly affect children's time allocation by influencing the working status of their parents with specific characteristics.

\subsubsection{Direct effects of PNTR on child labor}

We divide our data by gender, age and urban/rural location of children and by educational level of parents. We then study the effects of PNTR on child labor for different types of children. The results are reported in Table 8, indicating that the PNTR significantly increases the incidence of child labor for girls rather than boys. The results are consistent with the previous findings in the literature, i.e., girls are at higher risk of engaging in child labor. Trade liberalization does not have a significant effect on children aged between 6 and 12, whereas it does have a significant effect on children aged between 13 and 17. The trade effect is greater for older children: a one percentage point permanent decrease in export tariffs increases the incidence of child labor by 2.3 percentage points. In other words, children graduating from primary school are primarily responsible for the positive relationship between trade liberalization and the occurrence of child labor. Moreover, China's accession to the WTO only induces rural children to engage in child labor. Finally, trade liberalization only induces children with less-educated parents to engage more in child labor after trade liberalization. Children with educated parents are not significantly affected by trade liberalization.

[Table 8 about here]

PNTR may have caused an increase in the incidence of child labor for girls via two mechanisms: (1) trade liberalization induces more jobs for female workers, and (2) when girls and boys face the same employment opportunities, parents tend to send girls to work. In Figure 5, we apply the percentage of female workers in total employment for an industry in 2000 as a measure of female intensity of the industry. Figure 5 shows that there is a positive and statistically significant relationship 
between female intensity and industries' exposure to tariff reductions. Additionally, the insignificant effects of the gender of children on the incidence of child labor in all specifications of Tables 4 and 5 suggest that in China, parents are not more likely to send girls to work.

[Figure 5 about here]

Table 9 provides further evidence for the first mechanism instead of the second by presenting the effects of PNTR on the employment status of parents. We divide the sample by the gender and educational level of parents. In columns (1)-(4), we define less-educated parents as those with junior high or below education and educated parents as those with senior high or above education. Column (1) of Table 9 shows that trade liberalization increases less-educated mothers' likelihood of being employed. However, as shown in column (2), trade liberalization does not have a significant effect on the employment status of educated mothers. The results in columns (3) and (4) imply that the employment status of fathers, whether educated or less-educated, is not significantly affected by China's accession to the WTO. The four columns also confirm that trade liberalization demands more female laborers than males, particularly low-skilled female workers. Moreover, the magnitude of the effect for less-educated mothers is greater than that for child labor, which suggests that child labor, especially girl labor, supplements the demand for adult female labor. Notably, the unemployment rate of mothers is commensurate with that of fathers, which rejects the hypothesis that the smaller trade effect on the employment status of fathers is due to the high employment rate of fathers.

\section{[Table 9 about here]}

In columns (5) and (6) of Table 9, we further divide the less-educated mothers into those with primary or below education and those with junior high education. We find a significantly positive effect of trade liberalization on the employment of mothers with primary or below education in the year 2004 and a significantly positive effect on the employment of mothers with junior high education in the year 2006, 5 
years after China's entry into the WTO. The results in the two columns suggest that trade liberalization may lead to the skill upgrading of exporting industries.

\subsubsection{Indirect effects of PNTR on children's time allocation}

Trade liberalization creates more employment opportunities for less-educated mothers. The labor reallocation within households may induce their children to perform housework that would have been performed by mothers had they not been in the labor market, thus crowding out the children's time for study. In Table 10, we investigate the effects of PNTR on children's time allocation to housework, including buying food, cooking, and washing clothes, for families in which mothers are less-educated (having junior high education or below). Again, we divide the less-educated mothers further into those with primary or less education and those with junior high education. Trade liberalization induces children whose mothers have primary or below education to spend more time, primarily in 2004, on buying food for families. However, it induces children with mothers having junior high education to spend more time on cooking and washing clothes in 2009 or after, which is consistent with the evidence of long-term skill-upgrading.

[Table 10 about here]

Given all the heterogeneous effects of PNTR on child labor and children's time allocation, trade liberalization tends to enlarge, at least in the short term, the inequality of human capital accumulation between boys and girls, urban children and rural children, and children with more-educated parents and those with less-educated parents.

\subsection{Alternative Measures and Models}

\subsubsection{Tariff uncertainty}

In this paper, we assume that the annual potential tariff reductions before and after China's accession to the WTO are the same, i.e., the NTR gap. However, the uncertainty of tariff rates before 2001 is associated with the annual renewals, which is 
reflected by the U.S. Congress' approval rate of China's NTR status. In this section, we apply an alternative measure of tariff reduction, i.e., the expected tariff reduction, to the regression.

If annual renewal had failed, China would have been subject to non-NTR tariff rates, and the tariff reduction would be 0 ; if annual renewal had been approved, China would have been qualified for the relatively low NTR tariff rates, and the tariff reduction would be the NTR gap. Thus, the reduction in China's expected export tariff rates before 2001 is NTR gap $\times A R_{t}$, where $A R_{t}$ denotes the U.S. Congress approval rate in year $t$ for granting the NTR to China. The approval rate is the ratio of the number of votes for the NTR to the total number of votes. PNTR removed the uncertainty associated with these annual renewals by permanently setting U.S. duties on Chinese imports at NTR levels. Thus, the reduction in expected export tariffs after 2001 is simply NTR gaps.

We interact the expected reduction in export tariff rates with a full set of year dummies and report the results in Table 11. The current year approval rates and lagged year approval rates are applied in columns (1) and (2), respectively. We find that estimates are statistically insignificant at the 5\% level before the year 2001 and become significant for the year 2004. The magnitudes of the effects suggest that the results are robust to alternative measures of tariff reduction.

[Table 11 about here]

\subsubsection{IV estimation}

In the previous sections, we employ a reduced form regression. In this section, we apply two-stage least squares (2SLS) estimation. The explanatory variable of interest is trade value (exports and imports) at the province level. The analysis in this section is based on the CHNS dataset in the years 2000 and 2004.

Column (1) in Table 12 shows the OLS results, which imply that an increase in trade value is associated with an increase in the incidence of child labor. Column (2) presents the estimates from 2SLS applying the interaction between the NTR gap and 
the post-PNTR dummy as an IV for the trade value. The $F$-statistic in the first stage is 19, suggesting that the interaction term is not a weak instrument. The IV estimate shows a similar effect as the OLS estimate. Columns (3)-(4) and (5)-(6) apply exports and imports, respectively, and the results remain the same.

[Table 12 about here]

\section{Conclusion}

In this paper, we exploit an exogenous trade policy change to identify the causal effect of trade liberalization on child labor in China. Using a generalized DID specification, we show that regions that have a higher employment share in industries with higher NTR gaps experience a more rapid rise in the child labor participation rate, along with a proportionate increase in the dropout rate of school-age children after the U.S. granting of PNTR to China. Whereas new employment opportunities for children created by trade liberalization may improve household welfare in the short term, they may lead to intergenerational transmission of poverty in the long run, as groups that are more vulnerable in terms of human capital accumulation, such as girls, rural children and children with less-educated parents, are more likely to choose employment over investment in education during trade liberalization.

Fortunately, trade liberalization does not widen such inequalities in the long term. In the long term, exporting firms are more likely to experience much faster skill upgrading and demand more skilled workers, thus decreasing the incidence of child labor. 


\section{References}

Acemoglu D., Robinson J., Johnson S., 2005. Institutions as a Fundamental Cause of Long-Run Growth, Handbook of Economic Growth, Vol. 1A, 386-472.

Busse, M., 2002. Do labor standards affect comparative advantage in developing countries? World Development 30, 1921-1932.

Cameron, A., Gelbach, J., Miller, D., 2008. Bootstrap-based improvements for inference with clustered errors. Review of Economics and Statistics 90(3), 414-427.

Cigno, A., Rosati, F., Guarcello, L., 2002. Does globalization increase child labor? World Development 30 (9), 1579-1589.

Davies, R.B., Voy, A., 2009. The effect of FDI on child labor, Journal of Development Economics 88(1), 59-66.

De Brauw, A., Giles, J., 2016. Migrant opportunity and the educational attainment of youth in rural China. The Journal of Human Resources, doi:10.3368/jhr.52.1.0813-5900R.

Dean, J.M., Lovely, M.E., 2010. Trade Growth, Production Fragmentation, and China's Environment, in: Feenstra, R., Wei, S. (Eds.), China's Growing Role in World Trade. University of Chicago Press, Chicago, pp. 429-469.

Edmonds, E.V., 2008. Child Labor, in: Schultz, T.P., Strauss, J. (Eds.), Handbook of Development Economics, Vol. 4. North-Holland, Amsterdam, pp. 3607-3709.

Edmonds, E.V., Pavcnika, N., 2005. The effect of trade liberalization on child labor, Journal of International Economics 65(2), 401-419.

Edmonds E.V., Pavcnika, N., 2006. International trade and child labor: Cross-country evidence, Journal of International Economics 68(1), 115-140.

Edmonds, E.V., Pavcnik, N., Topalova, P., 2010. Trade Adjustment and Human Capital Investments: Evidence from Indian Tariff Reform. American Economic Journal: Applied Economics 2(4): 42-75.

Edwards, S., 1993. Openness, Trade Liberalization, and Growth in Developing Countries, Journal of Economic Literature 31(3), 1358-1393.

Feenstra, R.C., Romalis, J., Schott, P.K., 2002. U.S. Imports, Exports and Tariff Data, 1989-2001. NBER Working Paper 9387.

Francois, J., Hoekman, B., 2010. Services Trade and Policy. Journal of Economic Literature 48(3), 642-692.

Gawande, K., Krishna, P., Robbins, M.J., 2006. Foreign Lobbies and US Trade Policy. The Review of Economics and Statistics 88 (3), 563-571.

Greenaway, D., Morgan, W., Wright, P., 2002. Trade Liberalization and Growth in Developing Countries, Journal of Development Economics 67, 229-244. 
Gunnarsson, V., Orazem, P., Sanchez, M., 2006. Child labor and school achievement in Latin America. World Bank Economic Review 20, 31-54.

Handley, K., 2014. Exporting Under Trade Policy Uncertainty: Theory and Evidence. Journal of International Economics 94(1), 50-66.

Handley, K., Limao, N., 2013. Policy Uncertainty, Trade and Welfare: Theory and Evidence for China and the U.S. NBER Working Paper No. 19376.

Handley, K., Limao, N., 2015. Trade and Investment under Policy Uncertainty: Theory and Firm Evidence. American Economic Journal: Economic Policy 7(4), 189-222.

He, H., 2016. Child labour and academic achievement: Evidence from Gansu Province in China. China Economic Review 38, 130-150.

Heady, C., 2003. The effect of child labor on learning achievement. World Development 31, 385-398.

International Labour Organization, 1973. C138 minimum age convention, Geneva: ILO.

Kassouf, A., McKee, M., Mossialos, E., 2001. Early entrance to the job market and its effects on adult health. Journal of Health Policy and Planning 16, 2-20.

Kis-Katos, K., Sparrow, R., 2011. Child Labor and Trade Liberalization in Indonesia, The Journal of Human Resources 46(4), 722-749.

Liu, K., 2016. Insuring against Health Shocks: Health Insurance and Household Choices. Journal of Health Economics 46, 16-32.

Maskus, K.E., 1997. Should Core Labor Standards be Imposed through International Trade Policy, World Bank Policy Research, Working Paper No. 1817.

Mayer, W., 1984. Endogenous Tariff Formation. American Economic Review 74(5), 970-985.

Neumayer, E., De Soysa, I., 2005. Trade Openness, Foreign Direct Investment and Child Labor, World Development 33(1), 43-63.

O’Donnell, O., Doorslaer, E., Rosati, F., 2005. Health effects of child work: Evidence from rural Vietnam. Journal of Population Economics 18(3), 437-467.

Parker, D., 1997. Health effects of child labour. The Lancet 350, 1395-1396.

Pierce, J.R., Schott, P.K., 2016. The Surprisingly Swift Decline of U.S. Manufacturing Employment, American Economic Review 106(7), 1632-1662.

Ray, R., 2003. The determinants of child labour and child schooling in Ghana. Journal of African Economics 11(4), 561-590.

Tang, C., Zhao, L., Zhao, Z., 2016. Child Labor in China. China Economic Review, doi: 10.1016/j.chieco.2016.05.006. 


\section{Figures and Tables}

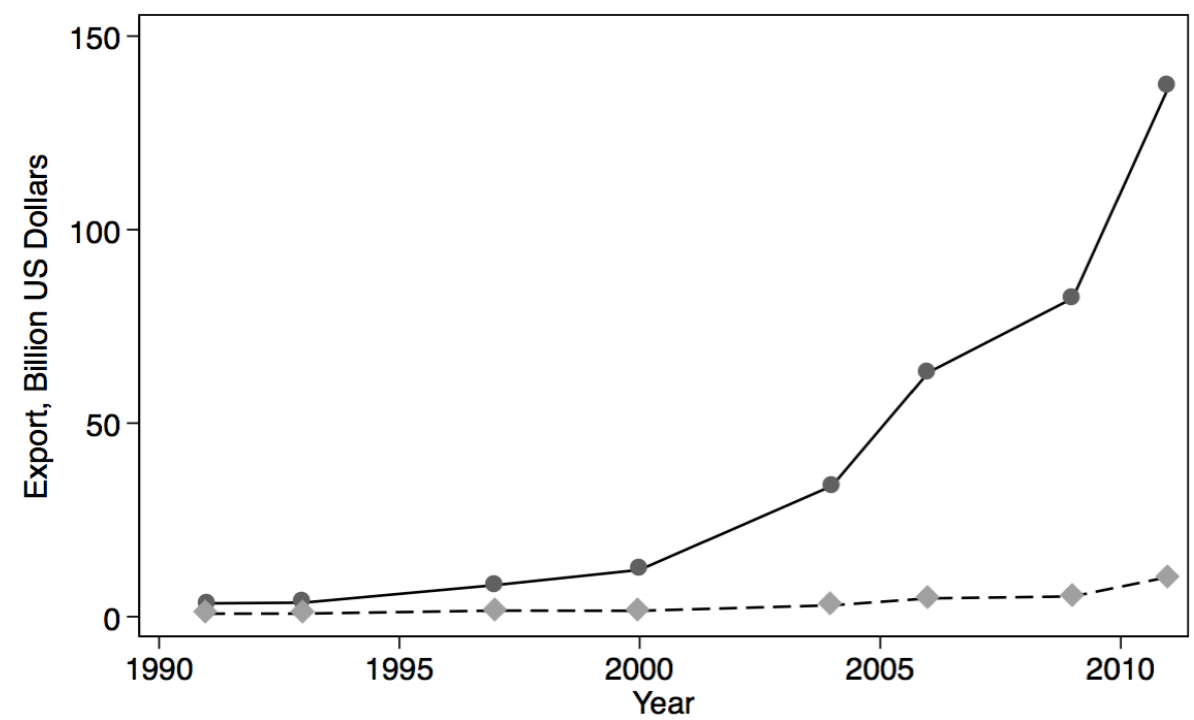

The four provinces having higher NTR gaps

- - The five provinces having lower NTR gaps

(A) Export Volume of China

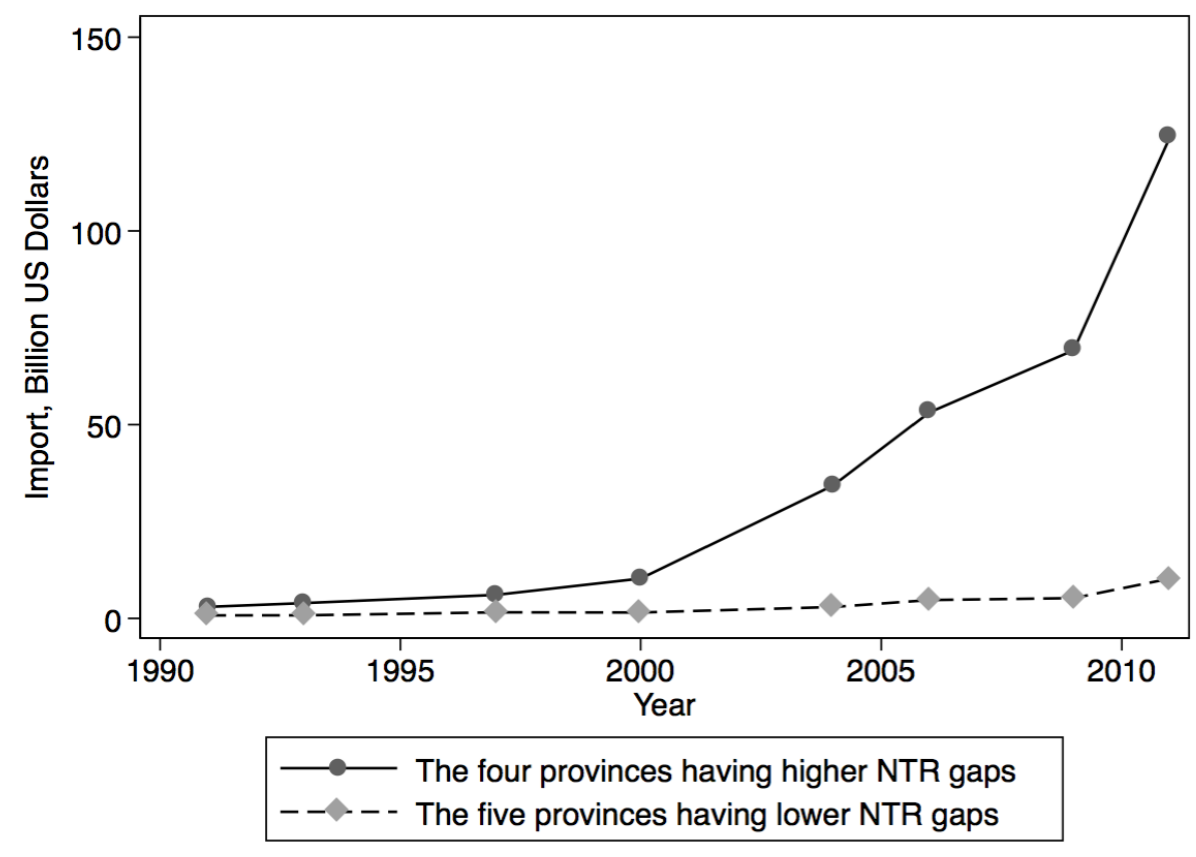

(B) Import Volume of China

Figure 1. Export and Import Volumes of China, Billion U.S. Dollars

Data Source: Trade data are from Chinese Statistical Yearbooks (various years).

Notes: The four provinces with higher NTR gaps include Jiangsu, Liaoning, Shandong, and Hubei. The five provinces with lower NTR gaps are Heilongjiang, Hunan, Henan, Guangxi, and Guizhou. 


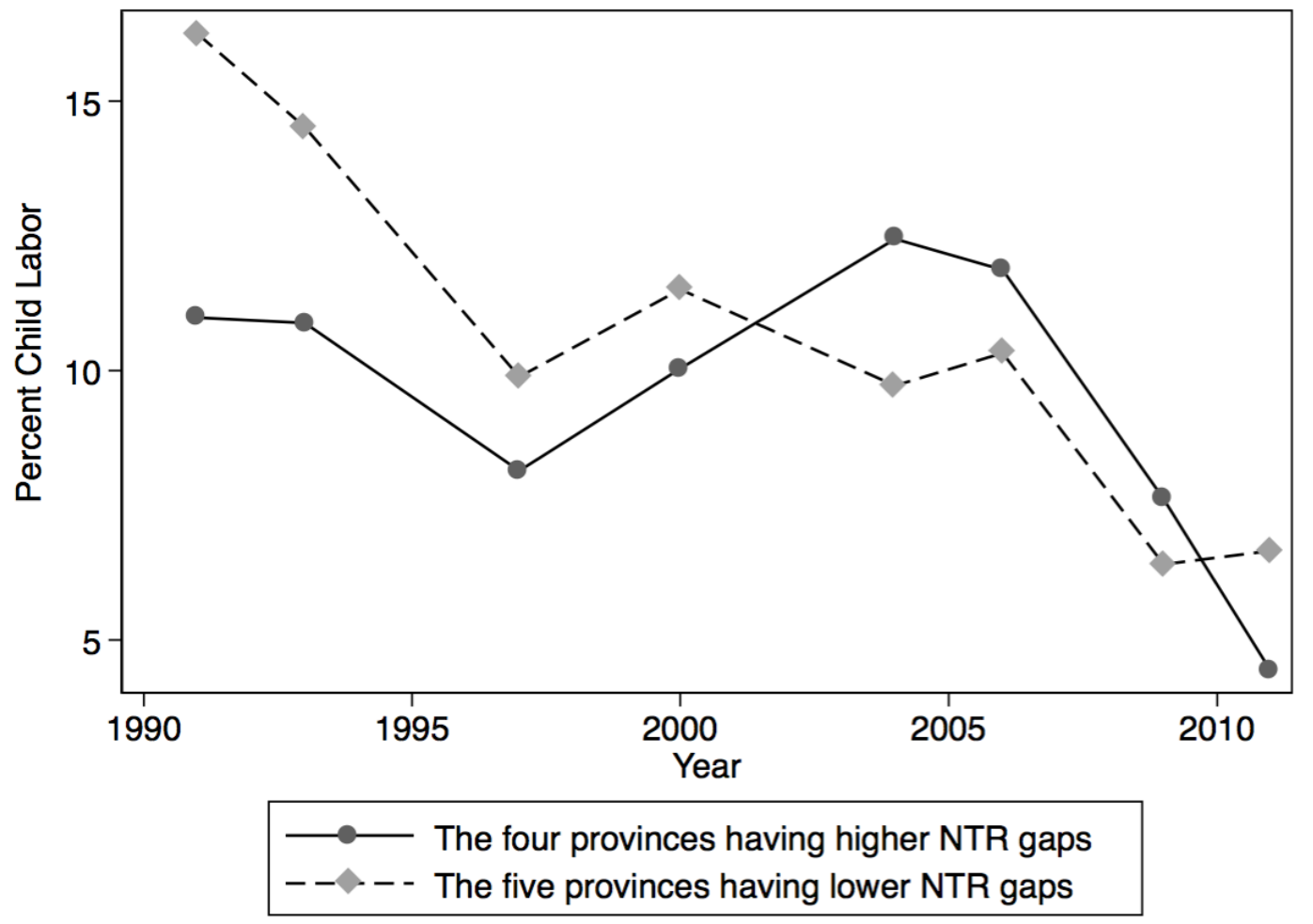

Figure 2. Percent Child Labor by NTR Gap

Data Source: Authors' own calculation from CHNS 1991, 1993, 1997, 2000, 2004, 2006, 2009 and 2011.

Notes: The four provinces with higher NTR gaps include Jiangsu, Liaoning, Shandong, and Hubei. The five provinces with lower NTR gaps are Heilongjiang, Hunan, Henan, Guangxi, and Guizhou. 


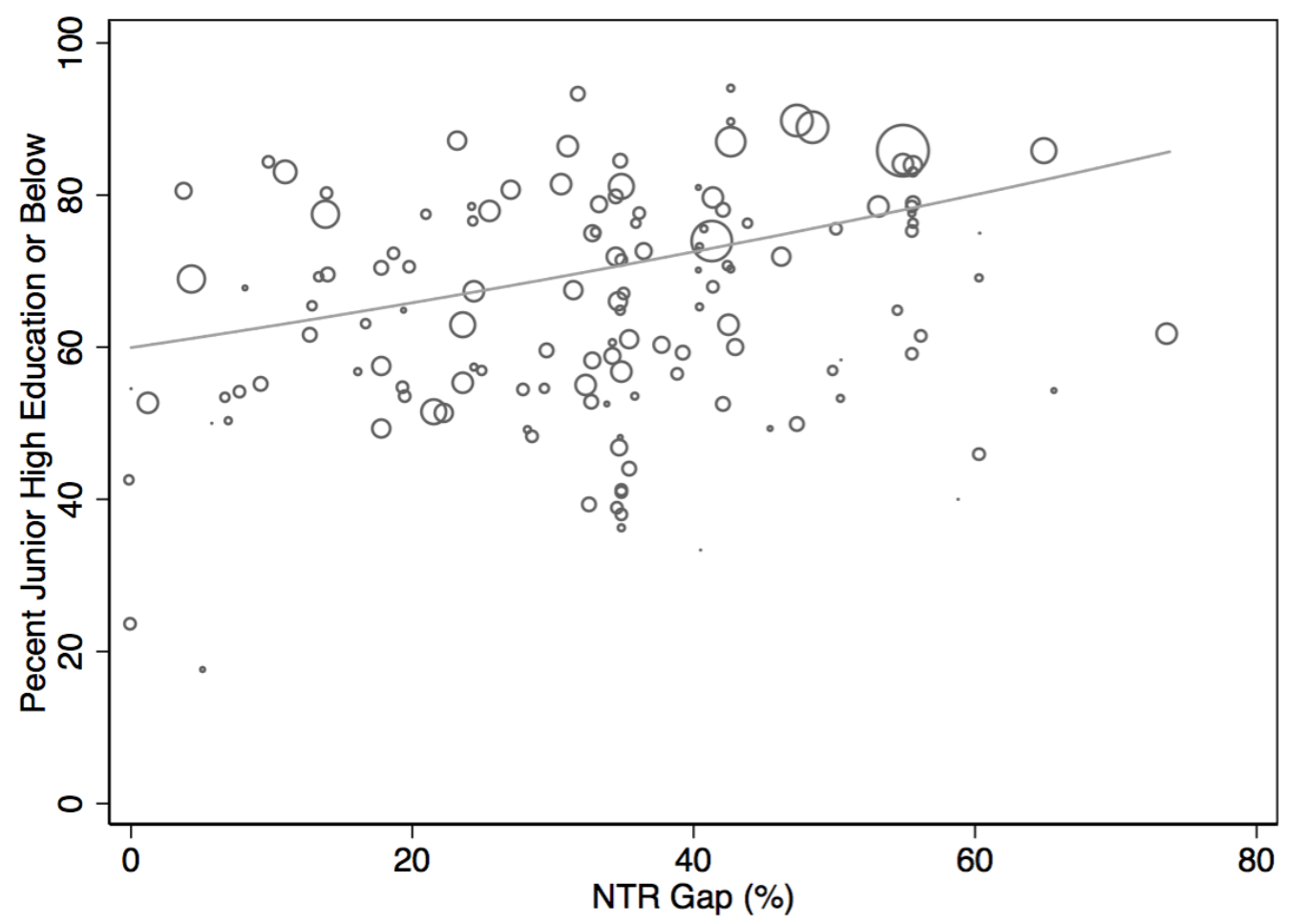

Figure 3. NTR Gaps and Skill Intensity

Data sources: $0.1 \%$ sample of the 2000 Population Census data and NTR gap constructed based on the data from Feenstra et al. (2002).

Notes: Circle sizes represent the total employment in a specific industry in 2000 . The curve is fitted by a quadratic regression model. 


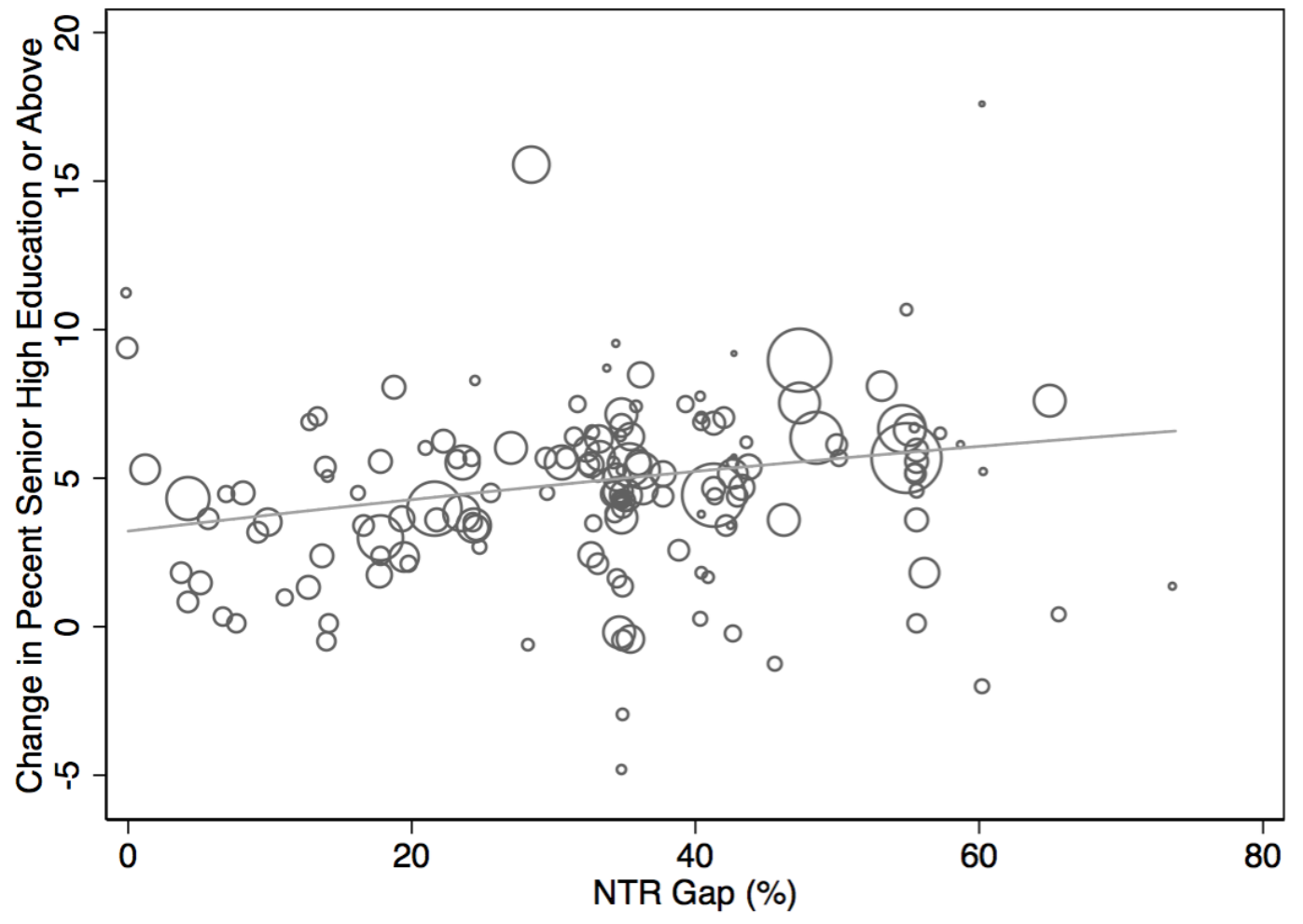

Figure 4. NTR Gaps and Skill Upgrading of Industries

Data sources: The National Economic Census (NEC) in 2004 and 2008 and the NTR gap constructed based on the data from Feenstra et al. (2002). The change in the percentage of employment with senior high or above education is measured by the difference in the percentage of employment with senior high or above education between 2008 and 2004, based on the data from the NEC.

Notes: Circle sizes represent the total employment in a specific industry in 2004. The curve is fitted by a quadratic regression model. 


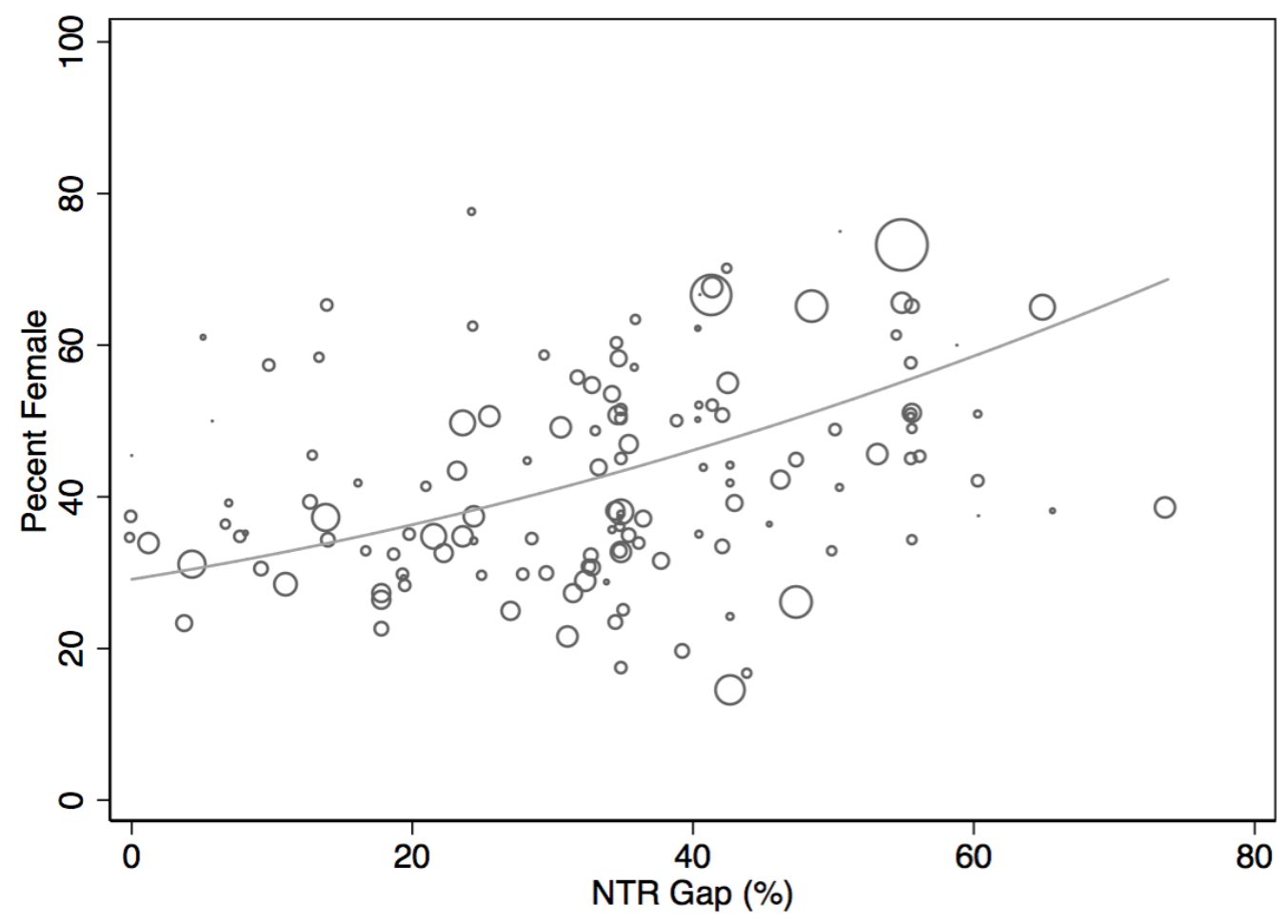

Figure 5. NTR Gaps and Female Intensity

Data sources: $0.1 \%$ sample of the 2000 Population Census data and the NTR gap constructed based on the data from Feenstra et al. (2002).

Notes: Circle sizes represent the total employment in a specific industry in 2000 . The curve is fitted by a quadratic regression model. 
Table 1. Percent Child Labor,

Overall and by Individual and Household Characteristics

\begin{tabular}{|c|c|c|c|c|c|c|c|c|c|}
\hline & 1991 & 1993 & 1997 & 2000 & 2004 & 2006 & 2009 & 2011 & All \\
\hline All & 14.1 & 12.9 & 9.3 & 10.9 & 10.8 & 10.9 & 6.8 & 6.0 & 10.6 \\
\hline \multicolumn{10}{|l|}{ Gender } \\
\hline Boys & 12.9 & 12.2 & 8.6 & 10.7 & 11.2 & 11.1 & 6.8 & 7.8 & 10.4 \\
\hline Girls & 15.5 & 13.7 & 10.0 & 11.0 & 10.4 & 10.5 & 6.8 & 3.9 & 10.8 \\
\hline \multicolumn{10}{|l|}{ Age } \\
\hline $6-12$ & 0.1 & 0.1 & 0.4 & 0.8 & 0.3 & 0.9 & 0.5 & 0.7 & 0.4 \\
\hline $13-15$ & 9.3 & 3.5 & 6.2 & 6.9 & 6.7 & 7.0 & 4.5 & 5.1 & 6.3 \\
\hline $16-17$ & 52.2 & 61.7 & 44.4 & 42.4 & 33.8 & 32.1 & 27.6 & 22.3 & 41.2 \\
\hline \multicolumn{10}{|l|}{ Location } \\
\hline Urban & 8.5 & 7.5 & 5.3 & 4.8 & 4.7 & 5.7 & 5.3 & 3.0 & 5.8 \\
\hline Rural & 16.0 & 14.8 & 10.9 & 13.1 & 12.9 & 12.6 & 7.3 & 6.9 & 12.3 \\
\hline \multicolumn{10}{|c|}{ Parents' Highest Education } \\
\hline Junior High or Above & 2.8 & 3.4 & 3.4 & 8.7 & 5.6 & 6.8 & 1.6 & 2.0 & 4.7 \\
\hline Junior High & 9.6 & 9.7 & 7.3 & 9.3 & 11.1 & 11.7 & 7.9 & 6.9 & 9.3 \\
\hline Primary or Below & 21.8 & 22.6 & 19.0 & 19.4 & 21.3 & 16.8 & 11.3 & 9.9 & 19.7 \\
\hline \multicolumn{10}{|c|}{ Household Income per Capita, Excluding Own Income } \\
\hline Upper Third & 9.6 & 8.3 & 5.3 & 6.2 & 5.6 & 7.5 & 5.7 & 3.8 & 6.7 \\
\hline Middle Third & 13.6 & 14.0 & 9.8 & 12.1 & 13.3 & 12.0 & 7.4 & 6.1 & 11.4 \\
\hline Lower Third & 19.2 & 16.4 & 12.9 & 14.5 & 13.5 & 13.1 & 7.6 & 7.9 & 13.8 \\
\hline Number of Observations & 2549 & 2540 & 2747 & 2591 & 2169 & 1914 & 1587 & 1527 & 17624 \\
\hline
\end{tabular}

Data Source: CHNS 1991, 1993, 1997, 2000, 2004, 2006, 2009 and 2011. 
Table 2. NTR Gaps by Province (\%)

\begin{tabular}{cc}
\hline Province & NTR Gap \\
\hline Jiangsu & 6.71 \\
Liaoning & 4.15 \\
Shandong & 3.43 \\
Hubei & 2.77 \\
Heilongjiang & 2.68 \\
Hunan & 1.86 \\
Henan & 1.51 \\
Guangxi & 1.41 \\
Guizhou & 1.13 \\
\hline
\end{tabular}

Data Sources: NTR gaps are constructed based on the ad valorem equivalent NTR and non-NTR tariff rates for 2000 provided by Feenstra et al. (2002). The province-level NTR gap is the employment-weighted average of NTR gaps for 3-digit industries.

Notes: in percentage points. 
Table 3. Effects of China's Accession to the WTO on Child Labor: Baseline Results

\begin{tabular}{|c|c|c|c|c|}
\hline Variables & $\begin{array}{c}(1) \\
\text { Child }\end{array}$ & $\begin{array}{c}(2) \\
\text { Child }\end{array}$ & $\begin{array}{c}(3) \\
\text { Child }\end{array}$ & $\begin{array}{c}(4) \\
\text { Child }\end{array}$ \\
\hline Post * NTR Gap & $\begin{array}{c}0.011 \\
(0.401)\end{array}$ & $\begin{array}{l}0.005^{*} \\
(0.081)\end{array}$ & $\begin{array}{c}0.007 * * * \\
(0.000)\end{array}$ & $\begin{array}{l}0.013 * \\
(0.067)\end{array}$ \\
\hline Boy & & $\begin{array}{l}-0.004 \\
(0.592)\end{array}$ & $\begin{array}{l}-0.002 \\
(0.704)\end{array}$ & $\begin{array}{l}-0.002 \\
(0.744)\end{array}$ \\
\hline Age & & $\begin{array}{c}-0.183^{* * *} \\
(0.001)\end{array}$ & $\begin{array}{c}-0.176^{* * *} \\
(0.001)\end{array}$ & $\begin{array}{c}-0.176^{* * *} \\
(0.001)\end{array}$ \\
\hline Age squared & & $\begin{array}{c}0.008 * * * \\
(0.000)\end{array}$ & $\begin{array}{c}0.008 * * * \\
(0.000)\end{array}$ & $\begin{array}{c}0.008^{* * *} * \\
(0.000)\end{array}$ \\
\hline Urban resident & & $\begin{array}{c}-0.065^{* * *} \\
(0.001)\end{array}$ & $\begin{array}{c}-0.047 * * * \\
(0.001)\end{array}$ & $\begin{array}{c}-0.047 * * * \\
(0.001)\end{array}$ \\
\hline Household size: 4 & & & $\begin{array}{c}0.006 \\
(0.301)\end{array}$ & $\begin{array}{c}0.006 \\
(0.296)\end{array}$ \\
\hline Household size: 5 & & & $\begin{array}{l}0.014 * \\
(0.060)\end{array}$ & $\begin{array}{l}0.014 * \\
(0.080)\end{array}$ \\
\hline Household size: 6-13 & & & $\begin{array}{c}0.019 * * * \\
(0.000)\end{array}$ & $\begin{array}{c}0.020 * * * \\
(0.004)\end{array}$ \\
\hline Mother's age & & & $\begin{array}{l}-0.009 * \\
(0.061)\end{array}$ & $\begin{array}{l}-0.009 * \\
(0.083)\end{array}$ \\
\hline Mother's age squared & & & $\begin{array}{c}0.000 \\
(0.107)\end{array}$ & $\begin{array}{c}0.000 \\
(0.131)\end{array}$ \\
\hline Father's age & & & $\begin{array}{l}-0.004 \\
(0.319)\end{array}$ & $\begin{array}{l}-0.004 \\
(0.273)\end{array}$ \\
\hline Father's age squared & & & $\begin{array}{c}0.000 \\
(0.244)\end{array}$ & $\begin{array}{c}0.000 \\
(0.216)\end{array}$ \\
\hline Mother's education: Junior high & & & $\begin{array}{c}-0.033 * * * \\
(0.001)\end{array}$ & $\begin{array}{c}-0.033 * * * \\
(0.008)\end{array}$ \\
\hline Mother's education: Senior high or above & & & $\begin{array}{c}-0.041 * * * \\
(0.001)\end{array}$ & $\begin{array}{c}-0.041 * * * \\
(0.001)\end{array}$ \\
\hline Father's education: Junior high & & & $\begin{array}{c}-0.020 * * * \\
(0.001)\end{array}$ & $\begin{array}{c}-0.020 * * * \\
(0.001)\end{array}$ \\
\hline Father's education: Senior high or above & & & $\begin{array}{c}-0.043 * * * \\
(0.001)\end{array}$ & $\begin{array}{c}-0.043 * * * \\
(0.001)\end{array}$ \\
\hline Household net income per capita, own income & & & $\begin{array}{c}-0.001 * * \\
(0.016)\end{array}$ & $\begin{array}{c}-0.001 * * \\
(0.024)\end{array}$ \\
\hline Constant & $\begin{array}{c}0.074 * * * \\
(0.000)\end{array}$ & $\begin{array}{c}1.536 * * * \\
(0.000)\end{array}$ & $\begin{array}{c}1.629 * * * \\
(0.000)\end{array}$ & $\begin{array}{c}1.634 * * * \\
(0.000)\end{array}$ \\
\hline Observations & 17,624 & 17,624 & 16,186 & 16,186 \\
\hline R-squared & 0.011 & 0.315 & 0.325 & 0.326 \\
\hline
\end{tabular}

Notes: Standard errors are clustered at the province level and are corrected for a small number of clusters via wild bootstrapping with 1,500 replications (Cameron et al., 2008). The wild-bootstrap P-values are reported in parentheses. $* * * \mathrm{p}<0.01, * * \mathrm{p}<0.05, * \mathrm{p}<0.1$. All columns also control for province dummies and year dummies. Columns (2)-(4) control for child's birth year dummies. Column (4) additionally includes province-specific linear year trends. 
Table 4. Effects of China's Accession to the WTO on Child Labor: Dynamic Effects

(1) (2) (3) (4)

Variables

Child labor Child labor Child labor Child labor

\begin{tabular}{|c|c|c|c|c|}
\hline $1\{$ year=1991\}×NTR Gap & $\begin{array}{l}-0.003 \\
(0.812)\end{array}$ & $\begin{array}{l}-0.002 \\
(0.813)\end{array}$ & $\begin{array}{l}-0.000 \\
(0.968)\end{array}$ & $\begin{array}{c}0.001 \\
(0.959)\end{array}$ \\
\hline $1\{$ year $=1993\} \times$ NTR Gap & $\begin{array}{c}0.006 \\
(0.715)\end{array}$ & $\begin{array}{c}0.005 \\
(0.415)\end{array}$ & $\begin{array}{c}0.007 \\
(0.340)\end{array}$ & $\begin{array}{c}0.008 \\
(0.691)\end{array}$ \\
\hline $1\{$ year $=1997\} \times$ NTR Gap & $\begin{array}{c}0.004 \\
(0.589)\end{array}$ & $\begin{array}{c}0.002 \\
(0.616)\end{array}$ & $\begin{array}{c}0.002 \\
(0.643)\end{array}$ & $\begin{array}{c}0.003 \\
(0.827)\end{array}$ \\
\hline $1\{$ year $=2004\} \times$ NTR Gap & $\begin{array}{c}0.015^{* * * *} \\
(0.000)\end{array}$ & $\begin{array}{c}0.010 * * * \\
(0.000)\end{array}$ & $\begin{array}{c}0.012 * * * \\
(0.000)\end{array}$ & $\begin{array}{c}0.012 * * \\
(0.039)\end{array}$ \\
\hline $1\{$ year $=2006\} \times$ NTR Gap & $\begin{array}{c}0.014 * * * \\
(0.000)\end{array}$ & $\begin{array}{c}0.007 * * \\
(0.015)\end{array}$ & $\begin{array}{c}0.009 * * * \\
(0.000)\end{array}$ & $\begin{array}{c}0.008 \\
(0.329)\end{array}$ \\
\hline $1\{$ year $=2009\} \times$ NTR Gap & $\begin{array}{c}0.011 \\
(0.209)\end{array}$ & $\begin{array}{c}0.008 \\
(0.317)\end{array}$ & $\begin{array}{c}0.011 \\
(0.223)\end{array}$ & $\begin{array}{c}0.010 \\
(0.425)\end{array}$ \\
\hline $1\{$ year $=2011\} \times$ NTR Gap & $\begin{array}{c}0.006 \\
(0.495)\end{array}$ & $\begin{array}{l}-0.000 \\
(0.916)\end{array}$ & $\begin{array}{c}0.001 \\
(0.747)\end{array}$ & $\begin{array}{l}-0.001 \\
(0.945)\end{array}$ \\
\hline Boy & & $\begin{array}{l}-0.004 \\
(0.584)\end{array}$ & $\begin{array}{l}-0.002 \\
(0.697)\end{array}$ & $\begin{array}{l}-0.002 \\
(0.691)\end{array}$ \\
\hline Age & & $\begin{array}{c}-0.182 * * * \\
(0.001)\end{array}$ & $\begin{array}{c}-0.176^{* * * *} \\
(0.001)\end{array}$ & $\begin{array}{c}-0.176^{* * *} \\
(0.001)\end{array}$ \\
\hline Squared age & & $\begin{array}{c}0.008 * * * \\
(0.000)\end{array}$ & $\begin{array}{c}0.008 * * * \\
(0.000)\end{array}$ & $\begin{array}{c}0.008 * * * \\
(0.000)\end{array}$ \\
\hline Urban resident & & $\begin{array}{c}-0.064 * * * \\
(0.001)\end{array}$ & $\begin{array}{c}-0.046 * * * \\
(0.001)\end{array}$ & $\begin{array}{c}-0.046 * * * \\
(0.001)\end{array}$ \\
\hline Household size: 4 & & & $\begin{array}{c}0.006 \\
(0.320)\end{array}$ & $\begin{array}{c}0.007 \\
(0.280)\end{array}$ \\
\hline Household size: 5 & & & $\begin{array}{l}0.014 * \\
(0.084)\end{array}$ & $\begin{array}{l}0.014 * \\
(0.064)\end{array}$ \\
\hline Household size: 6-13 & & & $\begin{array}{c}0.020 * * * \\
(0.000)\end{array}$ & $\begin{array}{c}0.020 * * * \\
(0.003)\end{array}$ \\
\hline Mother's age & & & $\begin{array}{c}-0.009 * \\
(0.053)\end{array}$ & $\begin{array}{l}-0.009 * \\
(0.079)\end{array}$ \\
\hline Squared mother's age & & & $\begin{array}{c}0.000 \\
(0.104)\end{array}$ & $\begin{array}{c}0.000 \\
(0.125)\end{array}$ \\
\hline Father's age & & & $\begin{array}{l}-0.004 \\
(0.301)\end{array}$ & $\begin{array}{l}-0.004 \\
(0.260)\end{array}$ \\
\hline Squared father's age & & & $\begin{array}{c}0.000 \\
(0.235)\end{array}$ & $\begin{array}{c}0.000 \\
(0.228)\end{array}$ \\
\hline Mother's education: Junior high & & & $\begin{array}{c}-0.033^{* * *} \\
(0.008)\end{array}$ & $\begin{array}{c}-0.033 * * * \\
(0.008)\end{array}$ \\
\hline Mother's education: Senior high or above & & & $\begin{array}{c}-0.041 * * * \\
(0.001)\end{array}$ & $\begin{array}{c}-0.041 * * * \\
(0.001)\end{array}$ \\
\hline
\end{tabular}


Table 4. Effects of China's Accession to the WTO on Child Labor: Dynamic Effects (Continuous)

(1)

(2)

(3)

Child labor Child labor Child labor Child labor

Variables

Father's education: Junior high

Father's education: Senior high or above

Household net income per capita,

own income excluded

Constant

Observations

R-squared

Notes: The dependent variable is being a child laborer. Standard errors are clustered at the province level and are corrected for a small number of clusters via wild bootstrapping with 1,500 replications (Cameron et al., 2008). The wild-bootstrap $\mathrm{p}$ values are reported in parentheses. $* * * \mathrm{p}<0.01, * * \mathrm{p}<0.05, * \mathrm{p}<0.1$. All columns also control for province dummies and year dummies. Columns (2)-(4) further control for child's birth year dummies. Column (4) additionally includes province-specific linear year trends. 
Table 5. Availability of Local Schools and Distance to Nearest School

\begin{tabular}{|c|c|c|c|c|}
\hline Variables & $\begin{array}{c}\text { (1) } \\
\text { Child Labor } \\
\text { Full Sample }\end{array}$ & $\begin{array}{c}\text { (2) } \\
\text { Child Labor } \\
\text { Full Sample }\end{array}$ & $\begin{array}{c}\text { (3) } \\
\text { Child Labor, } \\
\text { Rural Sample }\end{array}$ & $\begin{array}{c}\text { (4) } \\
\text { Child Labor, } \\
\text { Rural Sample }\end{array}$ \\
\hline $1\{$ year $=1991\} \times$ NTR Gap & $\begin{array}{c}0.004 \\
(0.821)\end{array}$ & $\begin{array}{c}0.004 \\
(0.840)\end{array}$ & $\begin{array}{c}0.008 \\
(0.571)\end{array}$ & $\begin{array}{c}0.008 \\
(0.697)\end{array}$ \\
\hline $1\{$ year $=1993\} \times$ NTR Gap & $\begin{array}{c}0.011 \\
(0.420)\end{array}$ & $\begin{array}{c}0.011 \\
(0.547)\end{array}$ & $\begin{array}{c}0.015 \\
(0.191)\end{array}$ & $\begin{array}{c}0.015 \\
(0.367)\end{array}$ \\
\hline $1\{$ year $=1997\} \times$ NTR Gap & $\begin{array}{c}0.003 \\
(0.675)\end{array}$ & $\begin{array}{c}0.005 \\
(0.533)\end{array}$ & $\begin{array}{c}0.009 \\
(0.241)\end{array}$ & $\begin{array}{c}0.010 \\
(0.235)\end{array}$ \\
\hline $1\{$ year $=2004\} \times$ NTR Gap & $\begin{array}{c}0.010 \\
(0.105)\end{array}$ & $\begin{array}{c}0.009 * * \\
(0.019)\end{array}$ & $\begin{array}{l}0.010 * \\
(0.095)\end{array}$ & $\begin{array}{l}0.009 * \\
(0.061)\end{array}$ \\
\hline $1\{$ year $=2006\} \times$ NTR Gap & $\begin{array}{c}0.004 \\
(0.631)\end{array}$ & $\begin{array}{c}0.005 \\
(0.639)\end{array}$ & $\begin{array}{c}0.003 \\
(0.655)\end{array}$ & $\begin{array}{c}0.005 \\
(0.668)\end{array}$ \\
\hline $1\{$ year $=2009\} \times$ NTR Gap & $\begin{array}{c}0.005 \\
(0.671)\end{array}$ & $\begin{array}{c}0.007 \\
(0.603)\end{array}$ & $\begin{array}{c}0.008 \\
(0.545)\end{array}$ & $\begin{array}{c}0.010 \\
(0.613)\end{array}$ \\
\hline $1\{$ year $=2011\} \times$ NTR Gap & $\begin{array}{l}-0.006 \\
(0.692)\end{array}$ & $\begin{array}{l}-0.005 \\
(0.764)\end{array}$ & $\begin{array}{l}-0.007 \\
(0.619)\end{array}$ & $\begin{array}{l}-0.004 \\
(0.788)\end{array}$ \\
\hline Have Primary & $\begin{array}{l}-0.010 \\
(0.140)\end{array}$ & & $\begin{array}{l}-0.013 \\
(0.188)\end{array}$ & \\
\hline Have Junior High & $\begin{array}{l}-0.001 \\
(0.932)\end{array}$ & & $\begin{array}{c}0.004 \\
(0.768)\end{array}$ & \\
\hline Have Senior High & $\begin{array}{l}-0.016 \\
(0.193)\end{array}$ & & $\begin{array}{l}-0.027 \\
(0.119)\end{array}$ & \\
\hline Log Distance to Primary & & $\begin{array}{c}0.001 \\
(0.552)\end{array}$ & & $\begin{array}{c}0.001 \\
(0.731)\end{array}$ \\
\hline Log Distance to Junior High & & $\begin{array}{c}0.002 \\
(0.597)\end{array}$ & & $\begin{array}{c}0.001 \\
(0.837)\end{array}$ \\
\hline Log Distance to Senior High & & $\begin{array}{l}0.005^{*} \\
(0.100)\end{array}$ & & $\begin{array}{l}0.006^{*} \\
(0.076)\end{array}$ \\
\hline Constant & $\begin{array}{c}1.595 * * * \\
(0.000)\end{array}$ & $\begin{array}{c}1.542 * * * \\
(0.000)\end{array}$ & $\begin{array}{c}1.710^{* * * *} \\
(0.000)\end{array}$ & $\begin{array}{c}1.655^{* * * *} \\
(0.000)\end{array}$ \\
\hline Observations & 15,844 & 14,990 & 11,837 & 11,200 \\
\hline R-squared & 0.327 & 0.325 & 0.364 & 0.361 \\
\hline
\end{tabular}

Notes: Standard errors are clustered at the province level and are corrected for a small number of clusters via wild bootstrapping with 1,500 replications (Cameron et al., 2008). The wild-bootstrap P-values are reported in parentheses. $* * * \mathrm{p}<0.01, * * \mathrm{p}<0.05, * \mathrm{p}<0.1$. All columns also control for child's gender, child's age and its square, mother's age and its square, father's age and its square, mother's education dummies, father's education dummies, living in urban or rural areas, household size dummies, household net income per capita excluding own income, province dummies, survey year dummies, child's birth year dummies, and province-specific linear year trends. "Have Primary", "Have Junior High" and "Have Senior High" represent whether a community or village owns a primary school, junior high school or senior high school. Distance to a school measures the distance between a community or village and the nearest school in kilometers. If a community or village owns a school, its distance to the school is 0 . We add a constant 0.1 to all distances before taking the logarithm of the distance. 
Table 6. Controlling for a New Cooperative Medical Scheme

(1)

(2)

Variables

Child labor, Full sample

Child labor, Rural sample

\begin{tabular}{|c|c|c|}
\hline $1\{$ year $=1991\} \times$ NTR Gap & $\begin{array}{l}-0.002 \\
(0.924)\end{array}$ & $\begin{array}{c}0.003 \\
(0.904)\end{array}$ \\
\hline $1\{$ year $=1993\} \times$ NTR Gap & $\begin{array}{c}0.006 \\
(0.733)\end{array}$ & $\begin{array}{c}0.010 \\
(0.508)\end{array}$ \\
\hline $1\{$ year $=1997\} \times$ NTR Gap & $\begin{array}{c}0.002 \\
(0.876)\end{array}$ & $\begin{array}{c}0.007 \\
(0.493)\end{array}$ \\
\hline $1\{$ year $=2004\} \times$ NTR Gap & $\begin{array}{l}0.014 * * \\
(0.017)\end{array}$ & $\begin{array}{l}0.013 * \\
(0.052)\end{array}$ \\
\hline $1\{$ year $=2006\} \times$ NTR Gap & $\begin{array}{c}0.011 \\
(0.224)\end{array}$ & $\begin{array}{c}0.009 \\
(0.336)\end{array}$ \\
\hline $1\{$ year $=2009\} \times$ NTR Gap & $\begin{array}{c}0.012 \\
(0.288)\end{array}$ & $\begin{array}{c}0.015 \\
(0.343)\end{array}$ \\
\hline $1\{$ year $=2011\} \times$ NTR Gap & $\begin{array}{c}0.003 \\
(0.840)\end{array}$ & $\begin{array}{r}0.002 \\
(0.899)\end{array}$ \\
\hline $\begin{array}{l}\text { New Cooperative Medical } \\
\text { Scheme }\end{array}$ & -0.010 & -0.004 \\
\hline Constant & $\begin{array}{c}(0.432) \\
1.634 * * * \\
(0.000)\end{array}$ & $\begin{array}{c}(0.828) \\
1.742 * * * \\
(0.000)\end{array}$ \\
\hline Observations & 16,139 & 12,098 \\
\hline R-squared & 0.327 & 0.363 \\
\hline
\end{tabular}

Notes: Standard errors are clustered at the province level and are corrected for a small number of clusters via wild bootstrapping with 1,500 replications (Cameron et al., 2008). The wild-bootstrap P-values are reported in parentheses. $* * * \mathrm{p}<0.01, * * \mathrm{p}<0.05, * \mathrm{p}<0.1$. All columns also control for child's gender, child's age and its square, mother's age and its square, father's age and its square, mother's education dummies, father's education dummies, living in urban or rural are, household size dummies, household net income per capita excluding own income, province dummies, survey year dummies, child's birth year dummies, and province-specific linear year trends. NCMS is set to be zero for all communities/villages before 2004 and is assumed to be equal to CMS in 2004 and thereafter. 
Table 7. Source and Working Status of Child Labor

(1)

(2)

(3)

\begin{tabular}{|c|c|c|c|}
\hline Variables & Child dropout & Child working & Child seeking jobs \\
\hline \multirow[t]{2}{*}{$1\{$ year $=1991\} \times$ NTR Gap } & -0.012 & -0.004 & 0.006 \\
\hline & $(0.664)$ & $(0.783)$ & $(0.549)$ \\
\hline \multirow[t]{2}{*}{$1\{$ year $=1993\} \times$ NTR Gap } & 0.000 & 0.005 & 0.003 \\
\hline & $(0.976)$ & $(0.785)$ & $(0.761)$ \\
\hline \multirow[t]{2}{*}{$1\{$ year $=1997\} \times$ NTR Gap } & 0.000 & -0.002 & 0.004 \\
\hline & $(0.979)$ & $(0.817)$ & $(0.111)$ \\
\hline \multirow[t]{2}{*}{$1\{$ year $=2004\} \times$ NTR Gap } & $0.016^{* *}$ & $0.009^{* *}$ & 0.003 \\
\hline & $(0.020)$ & $(0.047)$ & $(0.491)$ \\
\hline \multirow[t]{2}{*}{$1\{$ year $=2006\} \times$ NTR Gap } & 0.015 & 0.010 & -0.002 \\
\hline & $(0.348)$ & $(0.173)$ & $(0.828)$ \\
\hline \multirow[t]{2}{*}{$1\{$ year $=2009\} \times$ NTR Gap } & 0.016 & 0.015 & -0.005 \\
\hline & $(0.415)$ & $(0.185)$ & $(0.640)$ \\
\hline \multirow[t]{2}{*}{$1\{$ year $=2011\} \times$ NTR Gap } & 0.009 & 0.005 & -0.006 \\
\hline & $(0.744)$ & $(0.703)$ & $(0.616)$ \\
\hline \multirow[t]{2}{*}{ Constant } & $-1.117 * * *$ & $1.387 * * *$ & $0.238 * *$ \\
\hline & $(0.007)$ & $(0.000)$ & $(0.039)$ \\
\hline Observations & 15,164 & 16,186 & 16,186 \\
\hline R-squared & 0.248 & 0.286 & 0.048 \\
\hline
\end{tabular}

Notes: The dependent variable of column (1) is a dummy variable indicating whether a child has dropped out of school. The dependent variable of column (2) indicates whether a child is working. The dependent variable of column (3) stands for whether a child is seeking a job. Standard errors are clustered at the province level and are corrected for a small number of clusters via wild bootstrapping with 1,500 replications (Cameron et al., 2008). The wild-bootstrap p values are reported in parentheses. $* * * p<0.01$, $* * \mathrm{p}<0.05, * \mathrm{p}<0.1$. All columns also control for child's gender, child's age and its square, mother's age and its square, father's age and its square, mother's education dummies, father's education dummies, living in urban or rural areas, household size dummies, household net income per capita excluding own income, province dummies, survey year dummies, child's birth year dummies, and province-specific linear year trends. 
Table 8. Effects of China's Accession to the WTO on Child Labor, by Characteristics of Children and Households

\begin{tabular}{|c|c|c|c|c|c|c|c|c|}
\hline Variables & $\begin{array}{l}(1) \\
\text { Boy }\end{array}$ & $\begin{array}{l}(2) \\
\text { Girl }\end{array}$ & $\begin{array}{c}\text { (3) } \\
\text { Age } \\
6-12\end{array}$ & $\begin{array}{c}(4) \\
\text { Age } \\
13-17\end{array}$ & $\begin{array}{c}(5) \\
\text { Urban }\end{array}$ & $\begin{array}{c}\text { (6) } \\
\text { Rural }\end{array}$ & $\begin{array}{c}\text { (7) } \\
\text { Low } \\
\text { Parental } \\
\text { Education }\end{array}$ & $\begin{array}{c}(8) \\
\text { High } \\
\text { Parental } \\
\text { Education }\end{array}$ \\
\hline $1\{$ year $=1991\} \times$ NTR Gap & $\begin{array}{c}0.008 \\
(0.659)\end{array}$ & $\begin{array}{l}-0.007 \\
(0.849)\end{array}$ & $\begin{array}{c}0.002 \\
(0.784)\end{array}$ & $\begin{array}{l}-0.001 \\
(0.992)\end{array}$ & $\begin{array}{l}-0.010 \\
(0.808)\end{array}$ & $\begin{array}{c}0.003 \\
(0.879)\end{array}$ & $\begin{array}{c}0.001 \\
(0.937)\end{array}$ & $\begin{array}{c}0.004 \\
(0.964)\end{array}$ \\
\hline $1\{$ year $=1993\} \times$ NTR Gap & $\begin{array}{c}0.007 \\
(0.644)\end{array}$ & $\begin{array}{c}0.011 \\
(0.708)\end{array}$ & $\begin{array}{c}0.004 \\
(0.619)\end{array}$ & $\begin{array}{c}0.017 \\
(0.635)\end{array}$ & $\begin{array}{l}-0.003 \\
(0.945)\end{array}$ & $\begin{array}{c}0.010 \\
(0.515)\end{array}$ & $\begin{array}{c}0.008 \\
(0.627)\end{array}$ & $\begin{array}{c}0.012 \\
(0.699)\end{array}$ \\
\hline $1\{$ year $=1997\} \times$ NTR Gap & $\begin{array}{c}0.005 \\
(0.505)\end{array}$ & $\begin{array}{l}-0.000 \\
(0.980)\end{array}$ & $\begin{array}{c}0.004 \\
(0.263)\end{array}$ & $\begin{array}{c}0.002 \\
(0.932)\end{array}$ & $\begin{array}{l}-0.008 \\
(0.348)\end{array}$ & $\begin{array}{c}0.007 \\
(0.473)\end{array}$ & $\begin{array}{c}0.005 \\
(0.487)\end{array}$ & $\begin{array}{c}0.003 \\
(0.837)\end{array}$ \\
\hline $1\{$ year $=2004\} \times$ NTR Gap & $\begin{array}{c}0.006 \\
(0.632)\end{array}$ & $\begin{array}{c}0.019 * * \\
(0.012)\end{array}$ & $\begin{array}{c}0.000 \\
(0.808)\end{array}$ & $\begin{array}{c}0.023 * * \\
(0.039)\end{array}$ & $\begin{array}{c}0.006 \\
(0.471)\end{array}$ & $\begin{array}{l}0.013 * \\
(0.084)\end{array}$ & $\begin{array}{c}0.019 * * \\
(0.012)\end{array}$ & $\begin{array}{l}-0.005 \\
(0.780)\end{array}$ \\
\hline $1\{$ year $=2006\} \times$ & $\begin{array}{l}-0.004 \\
(0.769)\end{array}$ & $\begin{array}{l}0.023^{*} \\
(0.085)\end{array}$ & $\begin{array}{l}-0.001 \\
(0.799)\end{array}$ & $\begin{array}{c}0.018 \\
(0.347)\end{array}$ & $\begin{array}{c}0.007 \\
(0.617)\end{array}$ & $\begin{array}{c}0.008 \\
(0.423)\end{array}$ & $\begin{array}{c}0.009 \\
(0.511)\end{array}$ & $\begin{array}{c}0.004 \\
(0.832)\end{array}$ \\
\hline $1\{$ year $=2009\} \times$ NTR Gap & $\begin{array}{l}-0.005 \\
(0.829)\end{array}$ & $\begin{array}{c}0.029 \\
(0.161)\end{array}$ & $\begin{array}{l}-0.000 \\
(0.917)\end{array}$ & $\begin{array}{c}0.027 \\
(0.337)\end{array}$ & $\begin{array}{c}0.001 \\
(0.992)\end{array}$ & $\begin{array}{c}0.014 \\
(0.440)\end{array}$ & $\begin{array}{c}0.016 \\
(0.344)\end{array}$ & $\begin{array}{l}-0.005 \\
(0.885)\end{array}$ \\
\hline $1\{$ year $=2011\} \times$ NTR Gap & $\begin{array}{l}-0.022 \\
(0.385)\end{array}$ & $\begin{array}{c}0.024 \\
(0.349)\end{array}$ & $\begin{array}{l}-0.001 \\
(0.871)\end{array}$ & $\begin{array}{c}0.012 \\
(0.709)\end{array}$ & $\begin{array}{c}0.003 \\
(0.931)\end{array}$ & $\begin{array}{c}0.001 \\
(0.971)\end{array}$ & $\begin{array}{c}0.007 \\
(0.676)\end{array}$ & $\begin{array}{l}-0.016 \\
(0.731)\end{array}$ \\
\hline Constant & $\begin{array}{c}1.360 * * * \\
(0.000)\end{array}$ & $\begin{array}{c}1.931 * * * \\
(0.000)\end{array}$ & $\begin{array}{c}0.056 \\
(0.485) \\
\end{array}$ & $\begin{array}{c}5.157 * * * \\
(0.000)\end{array}$ & $\begin{array}{c}1.242 * * * \\
(0.007)\end{array}$ & $\begin{array}{c}1.745^{* * *} \\
(0.000) \\
\end{array}$ & $\begin{array}{c}1.753 * * * \\
(0.000) \\
\end{array}$ & $\begin{array}{c}0.891 \\
(0.160) \\
\end{array}$ \\
\hline Observations & 8,612 & 7,574 & 8,375 & 7,811 & 4,088 & 12,098 & 11,217 & 4,969 \\
\hline R-squared & 0.318 & 0.347 & 0.013 & 0.298 & 0.219 & 0.363 & 0.373 & 0.172 \\
\hline
\end{tabular}

Notes: Standard errors are clustered at the province level and are corrected for a small number of clusters via wild bootstrapping with 1,500 replications (Cameron et al., 2008). The wild-bootstrap P-values are reported in parentheses. ${ }^{* * *} \mathrm{p}<0.01, * * \mathrm{p}<0.05,{ }^{*} \mathrm{p}<0.1$. All columns also control for child's gender, child's age and its square, mother's age and its square, father's age and its square, mother's education dummies, father's education dummies, living in urban or rural areas, household size dummies, household net income per capita excluding own income, province dummies, year dummies, child's birth year dummies, and province-specific linear year trends. Low parental education indicates that the highest education level of parents is junior high school or below. High parental education indicates that the highest education level of parents is senior high school or above. 
Table 9. Effects of China's Accession to the WTO on Parental Employment, by Parental Education Level

\begin{tabular}{|c|c|c|c|c|c|c|}
\hline Variables & $\begin{array}{c}(1) \\
\text { Mother } \\
\text { Working: } \\
\text { Junior High } \\
\text { or Below }\end{array}$ & $\begin{array}{c}(2) \\
\text { Mother } \\
\text { Working: } \\
\text { Senior High } \\
\text { or Above }\end{array}$ & $\begin{array}{c}\text { (3) } \\
\text { Father } \\
\text { Working: } \\
\text { Junior High } \\
\text { or Below }\end{array}$ & $\begin{array}{c}(4) \\
\text { Father } \\
\text { Working: } \\
\text { Senior High } \\
\text { or Above }\end{array}$ & $\begin{array}{c}(5) \\
\text { Mother } \\
\text { Working: } \\
\text { Primary or } \\
\text { Below }\end{array}$ & $\begin{array}{c}\text { (6) } \\
\text { Mother } \\
\text { Working: } \\
\text { Junior High }\end{array}$ \\
\hline $1\{$ year $=1991\} \times$ NTR Gap & $\begin{array}{l}-0.001 \\
(0.976)\end{array}$ & $\begin{array}{c}0.032 \\
(0.555)\end{array}$ & $\begin{array}{c}0.025 \\
(0.435)\end{array}$ & $\begin{array}{l}-0.008 \\
(0.809)\end{array}$ & $\begin{array}{l}-0.010 \\
(0.567)\end{array}$ & $\begin{array}{c}0.000 \\
(0.989)\end{array}$ \\
\hline $1\{$ year $=1993\} \times$ NTR Gap & $\begin{array}{l}-0.004 \\
(0.797)\end{array}$ & $\begin{array}{c}0.034 \\
(0.405)\end{array}$ & $\begin{array}{c}0.015 \\
(0.541)\end{array}$ & $\begin{array}{l}-0.009 \\
(0.723)\end{array}$ & $\begin{array}{l}-0.015 \\
(0.311)\end{array}$ & $\begin{array}{c}0.009 \\
(0.845)\end{array}$ \\
\hline $1\{$ year $=1997\} \times$ NTR Gap & $\begin{array}{l}-0.006 \\
(0.605)\end{array}$ & $\begin{array}{c}0.036 \\
(0.152)\end{array}$ & $\begin{array}{c}0.000 \\
(0.988)\end{array}$ & $\begin{array}{l}-0.007 \\
(0.664)\end{array}$ & $\begin{array}{l}-0.011 \\
(0.105)\end{array}$ & $\begin{array}{l}-0.001 \\
(0.965)\end{array}$ \\
\hline $1\{$ year $=2004\} \times$ NTR Gap & $\begin{array}{l}0.028^{*} \\
(0.087)\end{array}$ & $\begin{array}{c}-0.008 \\
(0.828)\end{array}$ & $\begin{array}{l}-0.006 \\
(0.745)\end{array}$ & $\begin{array}{c}0.003 \\
(0.927)\end{array}$ & $\begin{array}{c}0.030^{* *} \\
(0.041)\end{array}$ & $\begin{array}{c}0.027 \\
(0.191)\end{array}$ \\
\hline $1\{$ year $=2006\} \times$ NTR Gap & $\begin{array}{c}0.036^{* *} \\
(0.020)\end{array}$ & $\begin{array}{c}0.021 \\
(0.533)\end{array}$ & $\begin{array}{l}-0.021 \\
(0.321)\end{array}$ & $\begin{array}{c}0.018 \\
(0.603)\end{array}$ & $\begin{array}{c}0.014 \\
(0.421)\end{array}$ & $\begin{array}{l}0.050^{*} \\
(0.059)\end{array}$ \\
\hline $1\{$ year $=2009\} \times$ NTR Gap & $\begin{array}{c}0.025 \\
(0.372)\end{array}$ & $\begin{array}{l}-0.005 \\
(0.931)\end{array}$ & $\begin{array}{l}-0.012 \\
(0.651)\end{array}$ & $\begin{array}{c}0.006 \\
(0.904)\end{array}$ & $\begin{array}{l}-0.005 \\
(0.911)\end{array}$ & $\begin{array}{c}0.041 \\
(0.483)\end{array}$ \\
\hline $1\{$ year $=2011\} \times$ NTR Gap & $\begin{array}{c}0.039 \\
(0.247)\end{array}$ & $\begin{array}{l}-0.020 \\
(0.768)\end{array}$ & $\begin{array}{l}-0.023 \\
(0.573)\end{array}$ & $\begin{array}{c}0.016 \\
(0.669)\end{array}$ & $\begin{array}{c}0.022 \\
(0.277)\end{array}$ & $\begin{array}{c}0.052 \\
(0.441)\end{array}$ \\
\hline Constant & $\begin{array}{c}1.097 \\
(0.124) \\
\end{array}$ & $\begin{array}{l}-0.312 \\
(0.835) \\
\end{array}$ & $\begin{array}{l}-0.295 \\
(0.733) \\
\end{array}$ & $\begin{array}{c}0.704 \\
(0.585) \\
\end{array}$ & $\begin{array}{l}0.967 * \\
(0.059) \\
\end{array}$ & $\begin{array}{c}0.903 \\
(0.515) \\
\end{array}$ \\
\hline Observations & 8,963 & 2,151 & 7,933 & 2,908 & 5,229 & 3,733 \\
\hline R-squared & 0.140 & 0.146 & 0.099 & 0.120 & 0.156 & 0.150 \\
\hline
\end{tabular}

Notes: Standard errors are clustered at the province level and are corrected for a small number of clusters via wild bootstrapping with 1,500 replications (Cameron et al., 2008). The wild-bootstrap P-values are reported in parentheses. $* * * \mathrm{p}<0.01, * * \mathrm{p}<0.05, * \mathrm{p}<0.1$. All columns also control for age and its square, education dummies, household size dummies, spouse's age and its square, spouse's education dummies, number of children, percent boys of children, children's average age and its square, living in urban or rural areas, household net income per capita excluding own income, province dummies, year dummies, birth year dummies, province-specific linear year trends and their squares. 
Table 10. China's Accession to the WTO on Whether Children Do Housework, by Mother's Education Level

\begin{tabular}{|c|c|c|c|c|c|c|}
\hline Variables & $\begin{array}{c}(1) \\
\text { Buying } \\
\text { Food } \\
\text { Primary or } \\
\text { Below }\end{array}$ & $\begin{array}{l}(2) \\
\text { Buying } \\
\text { Food } \\
\text { Junior } \\
\text { High }\end{array}$ & $\begin{array}{c}\text { Primary or } \\
\text { Below }\end{array}$ & $\begin{array}{c}(4) \\
\text { Cooking }\end{array}$ & $\begin{array}{c}(5) \\
\text { Washing } \\
\text { Clothes } \\
\text { Primary or } \\
\text { Below }\end{array}$ & $\begin{array}{c}\text { (6) } \\
\text { Washing } \\
\text { Clothes } \\
\text { Junior } \\
\text { High }\end{array}$ \\
\hline $1\{$ year $=1991\} \times$ NTR Gap & $\begin{array}{l}-0.023 \\
(0.413)\end{array}$ & $\begin{array}{l}-0.030 \\
(0.168)\end{array}$ & $\begin{array}{l}-0.024 \\
(0.496)\end{array}$ & $\begin{array}{l}-0.027 \\
(0.132)\end{array}$ & $\begin{array}{l}-0.026 \\
(0.553)\end{array}$ & $\begin{array}{l}-0.036 \\
(0.112)\end{array}$ \\
\hline $1\{$ year $=1993\} \times$ NTR Gap & $\begin{array}{l}-0.021 \\
(0.209)\end{array}$ & $\begin{array}{l}-0.018 \\
(0.371)\end{array}$ & $\begin{array}{l}-0.013 \\
(0.597)\end{array}$ & $\begin{array}{l}-0.020 \\
(0.141)\end{array}$ & $\begin{array}{l}-0.019 \\
(0.569)\end{array}$ & $\begin{array}{l}-0.024 \\
(0.281)\end{array}$ \\
\hline $1\{$ year $=1997\} \times$ NTR Gap & $\begin{array}{l}-0.001 \\
(1.000)\end{array}$ & $\begin{array}{l}-0.009 \\
(0.295)\end{array}$ & $\begin{array}{l}-0.010 \\
(0.476)\end{array}$ & $\begin{array}{l}-0.002 \\
(0.877)\end{array}$ & $\begin{array}{l}-0.008 \\
(0.663)\end{array}$ & $\begin{array}{l}-0.010 \\
(0.171)\end{array}$ \\
\hline $1\{$ year $=2004\} \times$ NTR Gap & $\begin{array}{c}0.027 * * * \\
(0.000)\end{array}$ & $\begin{array}{c}0.008 \\
(0.499)\end{array}$ & $\begin{array}{c}0.023 \\
(0.291)\end{array}$ & $\begin{array}{c}0.015 \\
(0.208)\end{array}$ & $\begin{array}{c}0.024 \\
(0.263)\end{array}$ & $\begin{array}{c}0.031 \\
(0.140)\end{array}$ \\
\hline $1\{$ year $=2006\} \times$ NTR Gap & $\begin{array}{l}0.018 * \\
(0.059)\end{array}$ & $\begin{array}{c}0.017 \\
(0.328)\end{array}$ & $\begin{array}{c}0.020 \\
(0.535)\end{array}$ & $\begin{array}{c}0.012 \\
(0.355)\end{array}$ & $\begin{array}{c}0.026 \\
(0.421)\end{array}$ & $\begin{array}{c}0.034 \\
(0.137)\end{array}$ \\
\hline $1\{$ year $=2009\} \times$ NTR Gap & $\begin{array}{c}0.027 \\
(0.277)\end{array}$ & $\begin{array}{c}0.022 \\
(0.355)\end{array}$ & $\begin{array}{c}0.035 \\
(0.363)\end{array}$ & $\begin{array}{l}0.029 * \\
(0.083)\end{array}$ & $\begin{array}{c}0.027 \\
(0.555)\end{array}$ & $\begin{array}{l}0.051^{*} \\
(0.092)\end{array}$ \\
\hline $1\{$ year $=2011\} \times$ NTR Gap & $\begin{array}{l}0.039 * \\
(0.069)\end{array}$ & $\begin{array}{c}0.032 \\
(0.273)\end{array}$ & $\begin{array}{c}0.041 \\
(0.365)\end{array}$ & $\begin{array}{l}0.034 * \\
(0.091)\end{array}$ & $\begin{array}{c}0.018 \\
(0.725)\end{array}$ & $\begin{array}{c}0.061 \\
(0.103)\end{array}$ \\
\hline Constant & $\begin{array}{l}0.346^{*} \\
(0.055) \\
\end{array}$ & $\begin{array}{c}0.231 \\
(0.652) \\
\end{array}$ & $\begin{array}{c}0.025 \\
(0.932) \\
\end{array}$ & $\begin{array}{c}0.383 \\
(0.231) \\
\end{array}$ & $\begin{array}{c}0.369 \\
(0.465) \\
\end{array}$ & $\begin{array}{c}1.202 * * \\
(0.024) \\
\end{array}$ \\
\hline Observations & 9,311 & 6,415 & 9,311 & 6,415 & 9,311 & 6,415 \\
\hline R-squared & 0.067 & 0.047 & 0.108 & 0.081 & 0.170 & 0.124 \\
\hline
\end{tabular}

Notes: Standard errors are clustered at the province level and are corrected for a small number of clusters via wild bootstrapping with 1,500 replications (Cameron et al., 2008). The wild-bootstrap P-values are reported in parentheses. ${ }^{* * *} \mathrm{p}<0.01,{ }^{* *} \mathrm{p}<0.05, * \mathrm{p}<0.1$. All columns also control for child's gender, child's age and its square, mother's age and its square, father's age and its square, mother's education dummies, father's education dummies, living in urban or rural areas, household size dummies, household net income per capita excluding own income, province dummies, year dummies, child's birth year dummies, and province-specific linear year trends. 
Table 11. Effects of Trade Volume on Child Labor,

OLS and 2SLS Regressions

\begin{tabular}{lcccccc}
\hline & $(1)$ & $(2)$ & $(3)$ & $(4)$ & $(5)$ & $(6)$ \\
Variables & OLS & 2SLS & OLS & 2SLS & OLS & 2SLS \\
\hline Total trade (100 billion U.S. dollars) & $0.052^{* * * *}$ & $0.058^{* * *}$ & & & & \\
& $(0.007)$ & $(0.010)$ & & & & \\
Export (100 billion U.S. dollars) & & & $0.109 * * *$ & $0.123^{* * *}$ & & \\
& & & $(0.016)$ & $(0.021)$ & & \\
Import (100 billion U.S. dollars) & & & & & $0.098^{* * *}$ & $0.110^{* * *}$ \\
& & & & & $(0.013)$ & $(0.020)$ \\
Constant & $0.954^{* * *}$ & $0.954^{* * * *}$ & $0.953^{* * *}$ & $0.952^{* * *}$ & $0.956^{* * *}$ & $0.955^{* * *}$ \\
& $(0.235)$ & $(0.220)$ & $(0.235)$ & $(0.220)$ & $(0.235)$ & $(0.220)$ \\
\hline F statistics for excluded instruments & & 19.0 & & 18.8 & & 19.2 \\
Observations & 4,406 & 4,406 & 4,406 & 4,406 & 4,406 & 4,406 \\
R-squared & 0.287 & 0.287 & 0.287 & 0.287 & 0.287 & 0.287 \\
\hline
\end{tabular}

Notes: Standard errors, in parentheses, are clustered at the province level. *** $\mathrm{p}<0.01, * * \mathrm{p}<0.05, * \mathrm{p}<0.1$ Only 2000 and 2004 data are used. The excluded instrument variable is NTR gap $* 2004$. Other control variables include child's gender, child's age and its square, mother's age and its square, father's age and its square, mother's education dummies, father's education dummies, living in urban or rural areas, household size dummies, household net income per capita excluding own income, province dummies, year dummy, and child's birth year dummies. 
Table 12. NTR Gaps Interacted with Approval Rates for the Sino-U.S. NTR by the U.S. Congress

(1)

\begin{tabular}{|c|c|c|}
\hline Variables & Child Labor & Child Labor \\
\hline \multirow[t]{2}{*}{$1\{$ year $=1991\} \times$ NTR Gap $\times A R_{1991}$} & 0.003 & \\
\hline & $(0.919)$ & \\
\hline \multirow[t]{2}{*}{$1\{$ year $=1993\} \times$ NTR Gap $\times A R_{1993}$} & 0.011 & \\
\hline & $(0.672)$ & \\
\hline \multirow[t]{2}{*}{$1\{$ year $=1997\} \times$ NTR Gap $\times A R_{1997}$} & 0.004 & \\
\hline & $(0.797)$ & \\
\hline \multirow[t]{2}{*}{$1\{$ year $=1991\} \times \mathrm{NTR}$ Gap $\times A R_{1990}$} & & 0.003 \\
\hline & & $(0.940)$ \\
\hline \multirow[t]{2}{*}{$1\{$ year $=1993\} \times$ NTR Gap $\times A R_{1992}$} & & 0.026 \\
\hline & & $(0.701)$ \\
\hline \multirow[t]{2}{*}{$1\{$ year $=1997\} \times$ NTR Gap $\times A R_{1996}$} & & 0.004 \\
\hline & & $(0.813)$ \\
\hline \multirow[t]{2}{*}{$1\{$ year $=2004\} \times N T R$ Gap } & $0.012 * *$ & $0.012^{*}$ \\
\hline & $(0.039)$ & $(0.064)$ \\
\hline \multirow[t]{2}{*}{$1\{$ year $=2006\} \times$ NTR Gap } & 0.008 & 0.008 \\
\hline & $(0.340)$ & $(0.329)$ \\
\hline \multirow[t]{2}{*}{$1\{$ year $=2009\} \times N T R$ Gap } & 0.010 & 0.010 \\
\hline & $(0.436)$ & $(0.407)$ \\
\hline \multirow[t]{2}{*}{$1\{$ year $=2011\} \times N T R$ Gap } & -0.001 & -0.001 \\
\hline & $(0.961)$ & $(0.977)$ \\
\hline \multirow[t]{2}{*}{ Constant } & $1.626 * * *$ & $1.626 * * *$ \\
\hline & $(0.000)$ & $(0.000)$ \\
\hline Observations & 16,186 & 16,186 \\
\hline $\mathrm{R}$-squared & 0.327 & 0.327 \\
\hline
\end{tabular}

Notes: Standard errors are clustered at the province level and are corrected for a small number of clusters via wild bootstrapping with 1,500 replications (Cameron et al., 2008). The wild-bootstrap P-values are reported in parentheses. $* * * \mathrm{p}<0.01, * * \mathrm{p}<0.05, * \mathrm{p}<0.1$. All columns also control for child's gender, child's age and its square, mother's age and its square, father's age and its square, mother's education dummies, father's education dummies, living in urban or rural areas, household size dummies, household net income per capita excluding own income, province dummies, year dummies, child's birth year dummies, and province-specific linear year trends. $A R_{t}$ denotes the U.S. Congress approval rate in year $t$ for granting the Normal Trade Relationship to China. The approval rate is the ratio of the number of votes for the NTR to the total number of votes. Table A1 summarizes the approval and disapproval votes in 1990-2001. 


\section{Appendix A. Supplementary Figures and Tables}

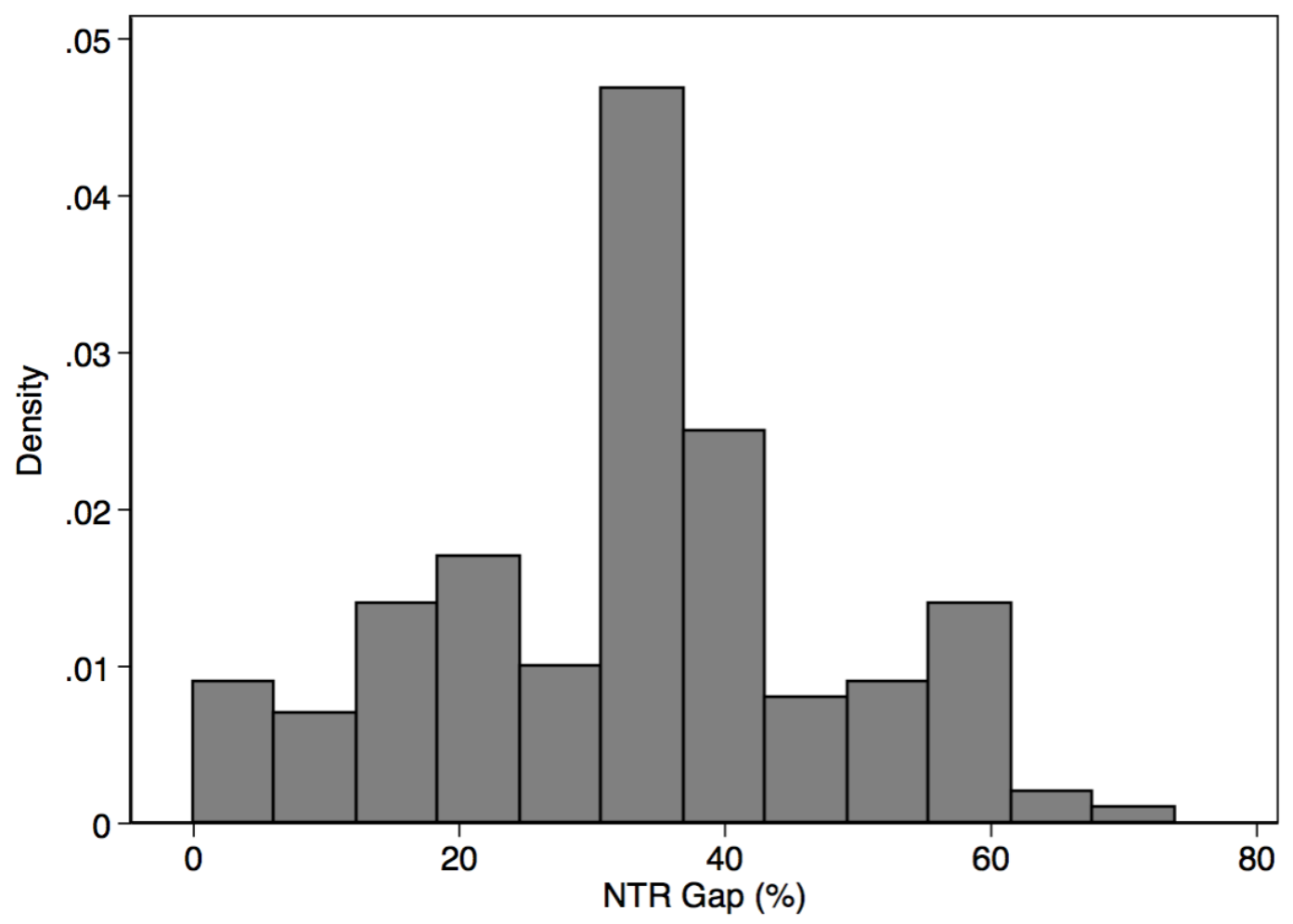

Figure A1. Distribution of NTR gaps across manufacturing industries, 2000

Data Source: NTR gaps are constructed based on the ad valorem equivalent NTR and non-NTR tariff rates for 2000 provided by Feenstra et al. (2002). 
Table A1. U.S. Votes to Overturn China's Temporary NTR Status, 1990-2001

\begin{tabular}{cccc}
\hline & \multicolumn{3}{c}{ House Votes for Continuation of China's NTR Status } \\
\cline { 2 - 4 } Year & Disapprove & Approve & \% Disapprove \\
\hline 1990 & 247 & 174 & 57 \\
1991 & 223 & 204 & 51 \\
1992 & 258 & 135 & 59 \\
1993 & 105 & 318 & 24 \\
1994 & 75 & 356 & 17 \\
1995 & 107 & 321 & 26 \\
1996 & 141 & 286 & 32 \\
1997 & 173 & 259 & 40 \\
1998 & 166 & 264 & 38 \\
1999 & 170 & 260 & 39 \\
2000 & 147 & 281 & 34 \\
2001 & 169 & 259 & 39 \\
Mean & 165 & 260 & 38 \\
\hline
\end{tabular}

Data Source: Pierce and Schott (2016). Total possible votes are 435. 